\title{
Hydroxyl radicals in the tropical troposphere over the Suriname rainforest: airborne measurements
}

\author{
M. Martinez ${ }^{1}$, H. Harder ${ }^{1}$, D. Kubistin ${ }^{1}$, M. Rudolf ${ }^{1}$, H. Bozem ${ }^{1}$, G. Eerdekens ${ }^{1}{ }^{*}$, H. Fischer ${ }^{1}$, T. Klüpfel ${ }^{1}$, C. Gurk ${ }^{1}$, \\ R. Königstedt ${ }^{1}$, U. Parchatka ${ }^{1}$, C. L. Schiller ${ }^{2}$, A. Stickler ${ }^{1}{ }^{* *}$, J. Williams ${ }^{1}$, and J. Lelieveld ${ }^{1}$ \\ ${ }^{1}$ Department of Atmospheric Chemistry, Max Planck Institute for Chemistry, Mainz, Germany \\ ${ }^{2}$ Department of Chemistry, York University, Toronto, Canada \\ *now at: Department of Biology, University of Antwerp, Belgium \\ *** now at: Institute for Atmospheric and Climate Science, ETH Zürich, Switzerland
}

Received: 1 July 2008 - Published in Atmos. Chem. Phys. Discuss.: 15 August 2008

Revised: 18 February 2010 - Accepted: 6 April 2010 - Published: 22 April 2010

\begin{abstract}
Direct measurements of $\mathrm{OH}$ and $\mathrm{HO}_{2}$ over a tropical rainforest were made for the first time during the GABRIEL campaign in October 2005, deploying the custom-built HORUS instrument (HydrOxyl Radical measurement Unit based on fluorescence Spectroscopy), adapted to fly in a Learjet wingpod. Biogenic hydrocarbon emissions were expected to strongly reduce the $\mathrm{OH}$ and $\mathrm{HO}_{2}$ mixing ratios as the air is transported from the ocean over the forest. However, surprisingly high mixing ratios of both $\mathrm{OH}$ and $\mathrm{HO}_{2}$ were encountered in the boundary layer over the rainforest.

The HORUS instrumentation and calibration methods are described in detail and the measurement results obtained are discussed. The extensive dataset collected during GABRIEL, including measurements of many other trace gases and photolysis frequencies, has been used to quantify the main sources and sinks of $\mathrm{OH}$. Comparison of these measurementderived formation and loss rates of $\mathrm{OH}$ indicates strong previously overlooked recycling of $\mathrm{OH}$ in the boundary layer over the tropical rainforest, occurring in chorus with isoprene emission.
\end{abstract}

Correspondence to: $\mathrm{M}$. Martinez (monica.martinez@mpic.de)

\section{Introduction}

The hydroxyl radical, $\mathrm{OH}$, is the atmosphere's most important oxidizer and cleansing agent. The hydroperoxy radical, $\mathrm{HO}_{2}$, is closely linked to $\mathrm{OH}$ in the atmosphere, and collectively they are referred to as $\mathrm{HO}_{\mathrm{x}}$. On a global scale, the main $\mathrm{OH}$ source in the lower troposphere is the photolysis of ozone producing an excited oxygen atom $\left(\mathrm{O}^{1} \mathrm{D}\right)$, which subsequently reacts with water to produce two $\mathrm{OH}$ radicals (Levy, 1971). Another source of $\mathrm{HO}_{\mathrm{x}}$ is the photolysis of formaldehyde, yielding two $\mathrm{HO}_{2}$ radicals for each formaldehyde photolyzed (Sander et al., 2006). In addition, $\mathrm{O}_{3}$ can react with terpenes yielding OH (Paulson and Orlando, 1996; Paulson et al., 1999). Since the latter source does not require photolysis, these reactions produce $\mathrm{OH}$ during day and night. On a diel average basis, however, photolytic sources are thought to contribute much more to primary $\mathrm{HO}_{\mathrm{x}}$ production than non-photolytic sources. The photolytic sources are especially strong in the tropics, where both humidity and irradiation intensity are high.

Once formed, $\mathrm{OH}$ and $\mathrm{HO}_{2}$ undergo rapid reactions that lead to efficient interconversion between these radicals. $\mathrm{OH}$ reacts with $\mathrm{CO}$ or $\mathrm{O}_{3}$ producing $\mathrm{HO}_{2}$, and the oxidation of hydrocarbons by $\mathrm{OH}$ leads to the formation of peroxy radicals, $\mathrm{RO}_{2}$, and $\mathrm{HO}_{2}$. In the presence of $\mathrm{NO}, \mathrm{RO}_{2}$ is converted to $\mathrm{HO}_{2}$, which reacts with $\mathrm{NO}$ or $\mathrm{O}_{3}$ to recycle $\mathrm{OH}$. The oxidation of hydrocarbons predominantly leads to the formation of formaldehyde (HCHO), increasing the source of $\mathrm{HO}_{\mathrm{x}}$. Tropical rainforests are a major source of volatile organic compounds (VOC) on a global scale, the dominant hydrocarbon being isoprene (Guenther et al., 1995). Isoprene

Published by Copernicus Publications on behalf of the European Geosciences Union. 
and other VOC are very reactive towards $\mathrm{OH}$ and therefore air influenced by forest emissions can be expected to have a markedly different $\mathrm{HO}_{\mathrm{x}}$ budget compared to both marine background and anthropogenically polluted air. The oxidation of large quantities of VOC over the rainforest, including isoprene, leads to the production of diverse organic $\mathrm{RO}_{2}$ radicals.

The main sink of $\mathrm{HO}_{\mathrm{x}}$ in the polluted boundary layer is the reaction of $\mathrm{OH}$ with $\mathrm{NO}_{2}$ forming nitric acid, $\mathrm{HNO}_{3}$. In air with low levels of nitrogen oxides, being predominant over the pristine rainforest, the reactions $\mathrm{HO}_{2}+\mathrm{HO}_{2}$ and $\mathrm{HO}_{2}+\mathrm{RO}_{2}$ are most important. These reactions form peroxides which are rapidly removed from the atmosphere by dry and wet deposition. Other sinks, such as radical deposition, heterogeneous chemistry on aerosols, multiphase cloud and rain chemistry and the formation of other chemical conmpounds such as pernitric acid are considered to be minor. Even though photolytic production of $\mathrm{OH}$ is highest in the tropics, over the rainforest a significant reduction of the oxidation capacity of the atmosphere is expected due to the strong emission of isoprene and other reactive organic species (e.g. Poisson et al., 2000; von Kuhlmann et al., 2004).

The GABRIEL campaign (Guyanas AtmosphereBiosphere exchange and Radicals Intensive Experiment with the Learjet) took place in October 2005 in Suriname, to study the influence of tropical rainforests and their emissions on the atmospheric oxidation capacity (Lelieveld et al., 2008; Stickler et al., 2007; Eerdekens et al., 2009). A suite of measurements relevant for studies of the photochemistry was performed using a Learjet 35A operated by the Gesellschaft für Flugzieldarstellung (GFD, Hohn, Germany). From the operational base, Johan A. Pengel International Airport in Zanderij, Suriname, 10 flights of about $3 \mathrm{~h}$ duration were performed between $3^{\circ} \mathrm{N} 59^{\circ} \mathrm{W}$ and $6^{\circ} \mathrm{N} 51^{\circ} \mathrm{W}$. Air was sampled upwind of the forest over the tropical Atlantic Ocean to the east of French Guiana, and over the rainforest at various distances from the coast over French Guiana, Suriname and Guyana. The flight patterns were planned using chemical weather forecasts (Lawrence et al., 2003) and allowed for sampling both in the boundary layer (BL) and in the free troposphere (FT), generally starting with an ascent up to an altitude of 6.5 to $8 \mathrm{~km}$ a.s.l., followed by a descent into the BL at 300 to $600 \mathrm{~m}$ a.s.l., followed by alternating legs in the BL and the FT up to an altitude of about 3 to $3.5 \mathrm{~km}$, and another ascent to levels above $6 \mathrm{~km}$ before landing.

\section{Instrumentation}

\subsection{Measurement technique}

$\mathrm{OH}$ and $\mathrm{HO}_{2}$ were measured with the HORUS instrument (HydrOxyl Radical measurement Unit based on fluorescence Spectroscopy), which uses laser-induced fluorescence (LIF)

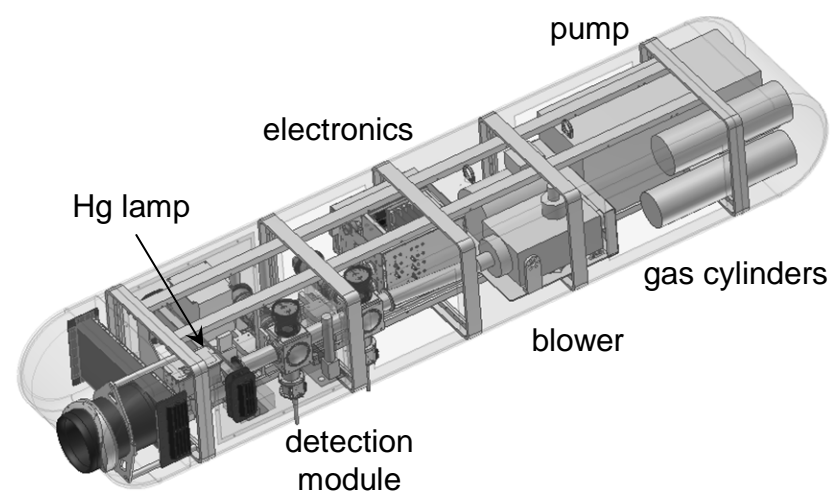

shrouded inlet

Fig. 1. Instrument setup in the wingpod.

of the $\mathrm{OH}$ molecule, based on the fluorescent assay by gas expansion (FAGE) technique originally proposed by Hard et al. (1984). HORUS was recently developed at our institute and adapted for measurements on the Learjet. The design of the detection module was originally based on ATHOS (Airborne Tropospheric Hydrogen Oxides Sensor), the Penn State $\mathrm{HO}_{\mathrm{x}}$ instrument described by Faloona et al. (2004). The detection module, together with pumps and gas cylinders, was mounted in a wingpod below the right wing, sampling the air directly from a forward-facing inlet to minimize surface effects (Fig. 1). The laser system is similar to the one in ATHOS, and consists of a tunable dye laser (Wennberg et al., 1994), pumped by a diode-pumped Nd:YAG laser (Navigator I J40-X30SC-532Q, Spectra Physics, Mountain View, $\mathrm{CA})$. The pulse frequency was set to $3 \mathrm{kHz}$. The two laser assemblies are mounted on either side of a rigid vertical plate, which was mounted on a rack inside the Learjet cabin. The laser light was channeled to the detection module through $10 \mathrm{~m}$ optical fibers through the wing.

The air sample was drawn through a pinhole nozzle (1.25 mm diameter) into a reduced pressure detection chamber by a system consisting of a rotary vane vacuum pump (Leybold TRIVAC D25B) combined with a supercharger (Eaton M90). The constant volume flow of about $10 \mathrm{slm}$ achieved with this pump system ensures an air speed through the detection area which is fast enough to exchange the air illuminated by the laser between two consecutive pulses to avoid possible laser-induced interferences. Different ambient pressures during flight lead to different internal pressures (2-5 hPa during GABRIEL), whereas the flow speed remains constant.

As the air flows through the laser beam, reflected in a White cell to cross the detection volume 32 times, the $\mathrm{OH}$ molecules are excited by laser pulses at $3 \mathrm{kHz}$ at one of several vibronic transition lines near $308 \mathrm{~nm}\left(A^{2} \Sigma-X^{2} \Pi\right.$, $v^{\prime}=0 \leftarrow v^{\prime \prime}=0$ ). The laser is tuned on and off resonance with the $\mathrm{OH}$ transition (called on-line and off-line) every $5 \mathrm{~s}$ to determine the $\mathrm{OH}$ fluorescence plus background signals and 
the background signals, respectively, resulting in a measurement time resolution of $10 \mathrm{~s}$. During GABRIEL the UV laser power entering the White cell was usually in the range of 3 to $6 \mathrm{~mW}$. The $\mathrm{OH}$ fluorescence extends beyond the prompt scattering (Rayleigh and wall scattering) and is detected with time-gated micro-channel plate detectors (Hamamatsu). The fluorescence decay is recorded with a time-resolution of $4 \mathrm{~ns}$ by a FPGA (field programmable gate array) and integrated for on- and off-line periods.

$\mathrm{HO}_{2}$ is measured simultaneously in a second detection cell located $16 \mathrm{~cm}$ downstream of the first cell through quantitative conversion into $\mathrm{OH}$ by reaction with $\mathrm{NO}$ (nitric oxide, $>99.5 \%$ ), purified through a sodium hydroxidecoated silica (Sigma-Aldrich Ascarite) followed by LIF detection of $\mathrm{OH}$. The NO is added through a loop between both cells and the NO flow is adjusted to achieve maximum yields of $\mathrm{OH}$, which are reached at internal mixing ratios of about $0.1 \%$ of NO.

Various tests were conducted during flights to ensure that observed $\mathrm{OH}$ signals were not influenced by instrument artefacts. The addition of reagent NO to the system was occasionally interrupted to verify that $\mathrm{HO}_{2}$ conversion does not take place in the $\mathrm{OH}$ detection cell. Scans of $0.1 \mathrm{~nm}$ of the $\mathrm{OH}$ spectrum conclusively showed that the observed signal was produced by $\mathrm{OH}$. To test for laser-generated $\mathrm{OH}$, the laser power was occasionally quickly reduced by $50 \%$; a laser-generated signal would decrease quadratically, the measured signal however always decreased proportionally, indicating the absence of laser-induced interference. The precision derived from the noise of the on- and off-line signals during the GABRIEL campaign was about $7 \%$ for $\mathrm{OH}$ and $1 \%$ for $\mathrm{HO}_{2}$. The average detection limits for $1 \mathrm{~min}$ integration times and a signal-to-noise ratio of 2 varied with altitude and ranged between $0.04 \mathrm{ppt}$ in the boundary layer and $0.02 \mathrm{ppt}$ at $8 \mathrm{~km}$ altitude for $\mathrm{OH}$, and around $0.08 \mathrm{ppt}$ for $\mathrm{HO}_{2}$.

\subsection{Shrouded inlet}

A front-facing shrouded inlet was designed to sample air directly into the wingpod and to allow for in-flight calibrations to complement the more extensive and thorough calibrations performed on the ground before and after each flight.

The design was based on the shrouded inlet described by Eisele et al. (1997). Our inlet consists of a shroud for alignment of the incoming air flow and only one tube ending with a deflector plate with a $90 \%$ blockage to decelerate the air. The original design was further adapted for integration into the wingpod using an outlet vent system at the sides of the wingpod. To allow for in-flight calibrations, a Hg lamp (LOT-Oriel Pen-Ray) was included in the assembly, the output of which was monitored by 2 phototubes, one attached directly to the lamp housing, the other at the far side of the inlet tube. The air speed within the inlet was monitored with a Pitot tube behind the nozzle.

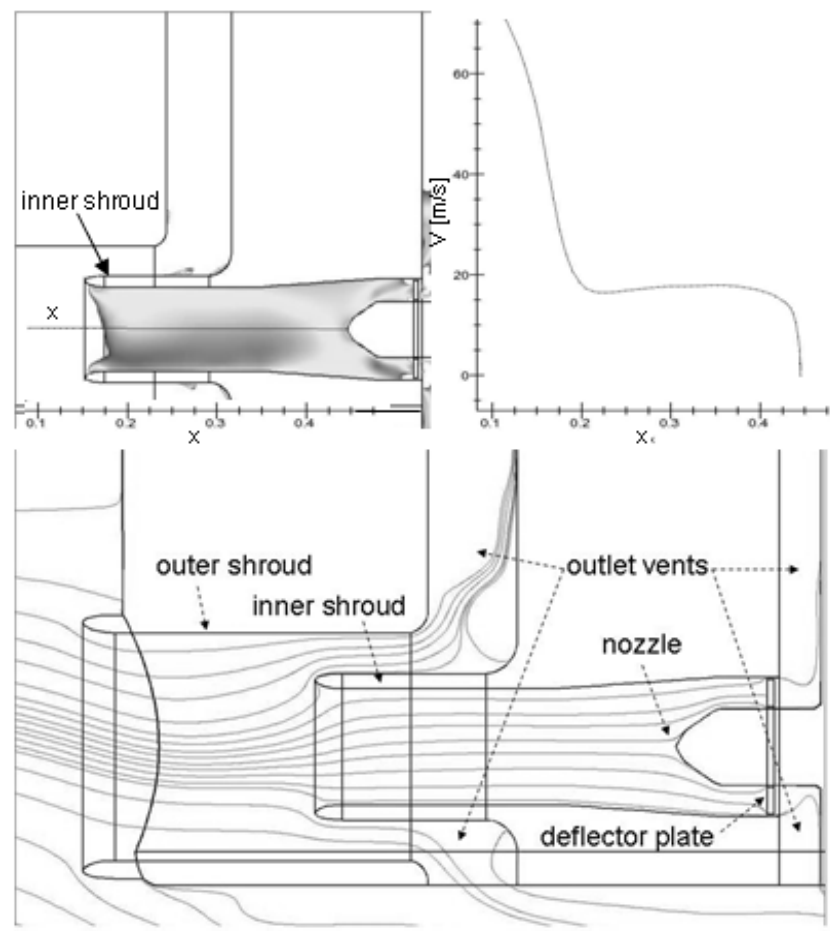

Fig. 2. Computational Fluid Dynamics calculations performed by H. Bijl and colleagues (Delft University). The velocity in the shrouded inlet is shown in the upper right panel, along the line indicated in the upper left panel. Streamlines in the shrouded inlet at an angle of attack of $15^{\circ}$ are shown in the lower panel.

Computational Fluid Dynamics calculations of air within the shrouded inlet were performed by P. Lucas, S. van Zuijlen and H. Bijl (Delft University of Technology, The Netherlands). The numerical results from these calculations indicate that our inlet assembly is capable of decelerating free stream velocities up to $200 \mathrm{~m} / \mathrm{s}$ to a value lower than $20 \mathrm{~m} / \mathrm{s}$ in the calibration section just in front of the sampling orifice, while maintaining a smooth flow, thus preventing vortices causing $\mathrm{OH}$ radical loss on the inlet walls (Fig. 2). The reduction of stream velocity is necessary for the in-flight calibration, to produce sufficient $\mathrm{OH}$ through the extended irradiation of the air by the Hg lamp. The velocity is still high enough to prevent any significant chemical losses while the air passes through the shrouded inlet. Calculations at an angle of attack other than zero show that the geometry of the wingpod with the inlet is capable of maintaining a smooth and attached flow even when the free-stream flow is deflected by up to 15 degrees.

The ultimate test of the adequacy of the inlet for $\mathrm{OH}$ sampling was provided by the measurements of naturally occurring $\mathrm{OH}$ made with this inlet during test flights and also during the GABRIEL campaign. The average angles flown by the Learjet during the GABRIEL flight were $(5 \pm 3)^{\circ}$ pitch and $(0 \pm 7)^{\circ}$ roll angle. Fast changes higher than $10^{\circ}$ in pitch and $20^{\circ}$ in roll angle within the $10 \mathrm{~s}$ resolution of the $\mathrm{OH}$ 

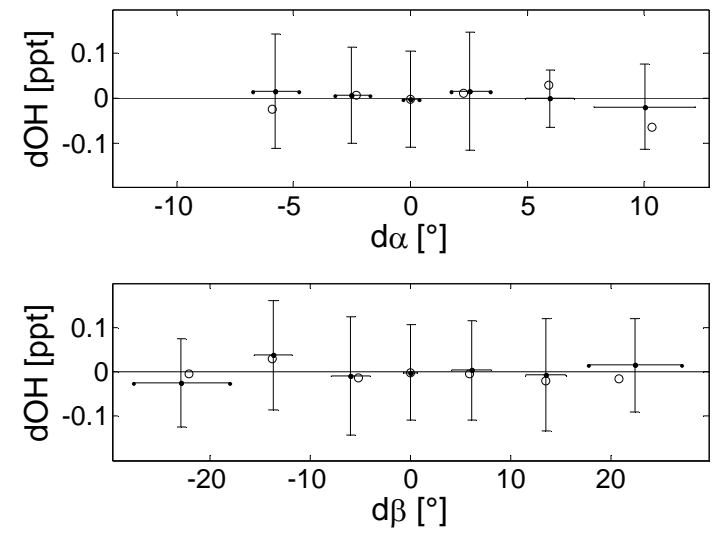

Fig. 3. Change in ambient $\mathrm{OH}$ mixing ratio measured within the $10 \mathrm{~s}$ resolution of the instrument as a function of change in pitch $(\alpha)$ and roll $(\beta)$, means ( $1 \sigma$ error bars) and medians (open circles) of $3^{\circ}$ bins for pitch and $7^{\circ}$ bins for roll angle change. We only included data collected when the Learjet was initially flying at average angles $\left((5 \pm 3)^{\circ}\right.$ pitch and $(0 \pm 7)^{\circ}$ roll $)$.

data do not lead to significant changes in the measured $\mathrm{OH}$ mixing ratios (Fig. 3).

\subsection{Calibration}

The instrument was calibrated thoroughly before or after each flight. In addition, relative calibrations took place during the flights to verify that different flight conditions did not have unexpected effects on the sensitivity.

The ground calibration technique is based on the method described by Faloona et al. (2004). A measured amount of air flows through the calibrator, a square aluminum tube, 16 $\mathrm{mm}$ wide and high. Water vapour is added to the air upstream of the flow tube and measured with an IR absorption instrument (LI-COR LI-7000), which is calibrated against a LI-COR dew point generator (LI-610). A Hg lamp, attached to the tube over a window, serves as a photolysis source for water vapour, producing equal amounts of $\mathrm{OH}$ and $\mathrm{HO}_{2}$ :

$\mathrm{H}_{2} \mathrm{O}+h v(184.9 \mathrm{~nm}) \rightarrow \mathrm{OH}+\mathrm{H}$,

$\mathrm{H}+\mathrm{O}_{2}+\mathrm{M} \rightarrow \mathrm{HO}_{2}$.

The lamp flux is calibrated by $\mathrm{N}_{2} \mathrm{O}$ photolysis (see Sect. 2.3.1). The overlap between the lamp flux field $(35 \mathrm{~mm} \times 16 \mathrm{~mm} \times 16 \mathrm{~mm})$ and the airflow field is calculated to determine the exposure time of the water vapour molecules to the $184.9 \mathrm{~nm}$ flux.

The concentration of $\mathrm{OH}$ is thus given by

$[\mathrm{OH}]=\left[\mathrm{HO}_{2}\right]=\Phi_{0} \sigma_{\mathrm{H} 2 \mathrm{O}}\left[\mathrm{H}_{2} \mathrm{O}\right] t f_{\mathrm{O} 2}$,

where $\Phi_{0}$ is the photon flux, $\sigma_{\mathrm{H} 2 \mathrm{O}}$ is the absorption cross section of $\mathrm{H}_{2} \mathrm{O}$ at $184.9 \mathrm{~nm}$, and $t$ is the exposure time. $f_{\mathrm{O} 2}$ is a correction factor to account for flux reduction through

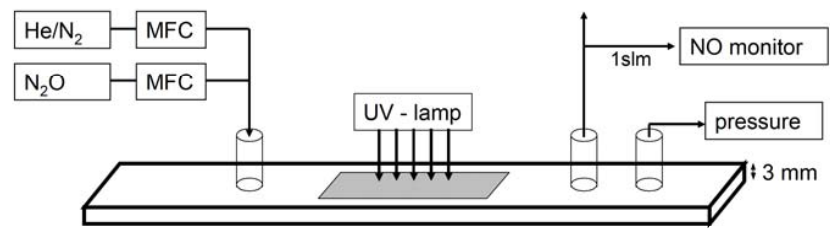

Fig. 4. Schematic representation of the photolysis chamber used for lamp flux calibration.

absorption by $\mathrm{O}_{2}$ across the tube height $h$ according to Lambert-Beer's law:

$f_{\mathrm{O} 2}=\frac{\Phi}{\Phi_{0}}=\frac{\int_{0}^{h} e^{-\sigma_{\mathrm{O} 2}\left[\mathrm{O}_{2}\right] x} d x}{h}$.

We used $\sigma_{\mathrm{H} 2 \mathrm{O}}=7.2 \times 10^{-20} \mathrm{~cm}^{2}$, as suggested by Heard and Pilling (2003), based on results by Cantrell et al. (1997) and Creasey et al. (2000).

The tube's outlet is placed near the instrument's inlet and the airflow set to $50 \mathrm{slm}$, such that the flow in the tube is turbulent (Reynolds number of 3500) with a flat velocity profile. The calibration flow is several times greater than the sampling flow of the instrument, overfilling the volume around the instrument nozzle to ensure that no ambient air is mixed in. Within the tube the air is well mixed, as indicated by $\mathrm{OH}$ and $\mathrm{HO}_{2}$ measurements constant to within $15 \%$ when the instruments inlet nozzle was placed at various positions within the tube's cross section. For calibrations the inlet nozzle was always positioned in the center.

The photon flux reduction due to $\mathrm{O}_{2}$ absorption was $5 \%$. Due to the short transit time of the air between the lamp and the instrument inlet of less than $10 \mathrm{~ms}$, chemical losses are negligible. Wall loss of $\mathrm{OH}$ radicals within the calibration tube between the lamp and the instrument inlet was $6 \%$. The wall loss was quantified as described by Faloona et al. (2004) by using a longer calibration tube with three equidistant windows. By situating the $\mathrm{Hg}$ lamp module at each of the three windows in the calibrator consecutively, a measure of the wall loss within the calibrator can be extrapolated to the inlet of the instrument. Results agreed within 3\% for different water vapor concentrations and fluxes between 45 and $55 \mathrm{slm}$. For $\mathrm{HO}_{2}$ the wall loss was $2 \%$, significantly lower than for $\mathrm{OH}$ as might be expected.

\subsubsection{Determination of the photon flux of the mercury lamp}

The photon flux of the Hg lamp was determined in the laboratory directly before and after the campaign through $\mathrm{N}_{2} \mathrm{O}$ actinometry measurements in nitrogen and helium, similar to the calibration procedure described by Edwards et 

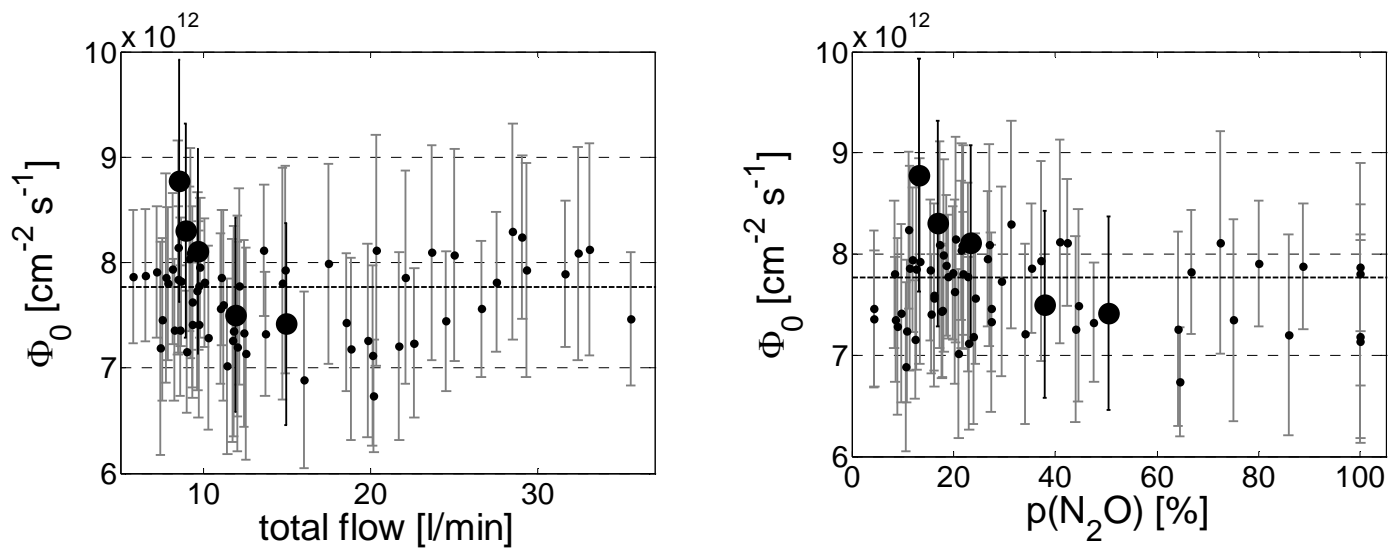

Fig. 5. Photon fluxes derived from $\mathrm{NO}$ yields from irradiation of $\mathrm{N}_{2} \mathrm{O}$ at different flow rates (left panel) and with different mixing ratios of $\mathrm{N}_{2} \mathrm{O}$ (right panel) in helium (small symbols) and nitrogen (large symbols) using the $3 \mathrm{~mm}$ photolysis chamber.

al. (2003). $\mathrm{N}_{2} \mathrm{O}$ photodissociates at $184.9 \mathrm{~nm}$ producing the excited oxygen atoms $\mathrm{O}\left({ }^{1} \mathrm{D}\right)$

$\mathrm{N}_{2} \mathrm{O}+h v \rightarrow \mathrm{O}\left({ }^{1} \mathrm{D}\right)+\mathrm{N}_{2}$

which is then collisionally quenched or reacts with $\mathrm{N}_{2}$ or $\mathrm{N}_{2} \mathrm{O}$ (Sander et al., 2006):

$\mathrm{O}\left({ }^{1} \mathrm{D}\right)+\mathrm{N}_{2}+\mathrm{M} \rightarrow \mathrm{N}_{2} \mathrm{O}$,

$\mathrm{O}\left({ }^{1} \mathrm{D}\right)+\mathrm{N}_{2} \rightarrow \mathrm{O}\left({ }^{3} \mathrm{P}\right)+\mathrm{N}_{2}$,

$\mathrm{O}\left({ }^{1} \mathrm{D}\right)+\mathrm{N}_{2} \mathrm{O} \rightarrow \mathrm{N}_{2}+\mathrm{O}_{2}$,

$\mathrm{O}\left({ }^{1} \mathrm{D}\right)+\mathrm{N}_{2} \mathrm{O} \rightarrow 2 \mathrm{NO}$,

$\mathrm{O}\left({ }^{1} \mathrm{D}\right)+\mathrm{N}_{2} \mathrm{O} \rightarrow \mathrm{O}\left({ }^{3} \mathrm{P}\right)+\mathrm{N}_{2} \mathrm{O}$.

The quenching Reaction (R3e) is negligible compared to the other reactions (Vranckx et al., 2008).

The flux can be calculated from the NO concentrations produced by irradiating defined mixtures of $\mathrm{N}_{2} \mathrm{O}$ in a carrier gas:

$\Phi_{0}=\frac{\left(k_{\mathrm{a}}\left[\mathrm{N}_{2}\right][\mathrm{M}]+k_{\mathrm{b}}\left[\mathrm{N}_{2}\right]+k_{\mathrm{c}}\left[\mathrm{N}_{2} \mathrm{O}\right]+k_{\mathrm{d}}\left[\mathrm{N}_{2} \mathrm{O}\right]\right)[\mathrm{NO}]}{2 k_{\mathrm{d}}\left[\mathrm{N}_{2} \mathrm{O}\right]^{2} \sigma_{\mathrm{N} 2 \mathrm{O}} f_{\mathrm{N} 2 \mathrm{O}} t}$,

where $\Phi_{0}$ is the actinic flux from the lamp, $\sigma_{\mathrm{N} 2 \mathrm{O}}$ is the absorption cross section of $\mathrm{N}_{2} \mathrm{O}$ at $184.9 \mathrm{~nm}$, and $f_{\mathrm{N} 2 \mathrm{O}}$ is a correction factor to account for flux reduction through absorption by $\mathrm{N}_{2} \mathrm{O}$.

The NO produced was measured using a TECO $42 \mathrm{C}$ (Thermo Environmental Instruments Inc.). In order to produce NO concentrations well above the detection limit of $50 \mathrm{ppt}\left(\mathrm{pmol} / \mathrm{mol}\right.$ ), $\mathrm{N}_{2} \mathrm{O}$ (Messer, 100\% UHP) was mixed into flows between 5 and $35 \mathrm{slm}$ to obtain various mixing ratios of $0-100 \%$. $\mathrm{N}_{2}$ or He was used as carrier gas. The benefit of using helium is the absence of the Reactions (R3a) and (R3b) and therefore a better signal to noise ratio, as $\mathrm{O}\left({ }^{1} \mathrm{D}\right)$ reaction with He is very slow (Preston and Cvetanovic, 1966).
At $18 \% \mathrm{~N}_{2} \mathrm{O}$ in $\mathrm{N} 2,50 \%$ of the $\mathrm{O}\left({ }^{1} \mathrm{D}\right)$ is removed by $\mathrm{N}_{2}$ (through Reactions R3a and R3b). In addition, the sensitivity of the TECO detector is about $50 \%$ higher for $\mathrm{NO}$ when $\mathrm{He}$ is used as a carrier gas in comparison to $\mathrm{N}_{2}$. However, due to the lower density and viscosity of helium, it becomes more difficult to achieve a turbulent flow with helium. To ensure a flat velocity profile of the $\mathrm{N}_{2} \mathrm{O}$ flow under all conditions considered, a flat $3 \mathrm{~mm}$ high photolysis chamber was employed (Fig. 4). Under these conditions, the flux reduction due to $\mathrm{N}_{2} \mathrm{O}$ absorption was up to $f_{\mathrm{N} 2 \mathrm{O}}=0.6$ depending on the $\mathrm{N}_{2} \mathrm{O}$ mixing ratio used. Depending on the flow through the photolysis chamber the inside pressure is higher than the ambient pressure (reaching up to 2.5 bar at $35 \mathrm{slm}$ total flow), which needs to be taken into account.

The results of the laboratory measurements are shown in Fig. 5. The photon fluxes measured using different carrier gases all agree within the respective uncertainties, showing no dependency on the gas flow or on the fraction of $\mathrm{N}_{2} \mathrm{O}$ in the gas mixture. Model simulations (Comsol, Femlab v3.1) indicate a turbulent flow in the photolysis chamber for a flow of $7 \mathrm{slm} \mathrm{N}_{2}$. The agreement of the measured photon fluxes confirms that the flow was turbulent under all conditions.

The systematic error of the lamp photon flux is a result of all uncertainties listed in Table 1 and is estimated to be $12 \%$.

Ideally the photon flux should be measured in the tube used for calibration of the LIF instrument and with the same gas flows. The high flow rate of $50 \mathrm{slm}$, however, leads to low $\mathrm{NO}$ yields from $\mathrm{N}_{2} \mathrm{O}$ photolysis, which were difficult to quantify with the routinely used TECO NO analyzer. A comparison of flux measurements performed with the calibration tube, sampling NO with a more sensitive CLD-780TR instrument (Eco Physics AG, detection limit 27 ppt) through a $1 / 8^{\prime \prime}$ Teflon tube integrated into a modified LIF instrument nozzle, is shown in Fig. 6. The values agree within error limits, even though the measurements with the calibration tube at low $\mathrm{N}_{2} \mathrm{O}$ mixing ratios yield about $10 \%$ larger values. 
Table 1. Systematic errors for lamp flux calibration.

\begin{tabular}{lc}
\hline & $1 \sigma$ error \\
\hline NO monitor (TECO) & $6 \%$ \\
NO standard (NIST) & $1 \%$ \\
Mass Flow Controllers (MKS) & $2 \%$ \\
$\mathrm{~N}_{2} \mathrm{O}$ cross section $\sigma_{\mathrm{N} 2 \mathrm{O}}$ & $2 \%$ \\
$\mathrm{O}\left({ }^{1} \mathrm{D}\right)$ yield & $1 \%$ \\
Kinetic rate coefficients & $12 \%$ \\
Photolysis chamber dimensions & $10 \%$ \\
Pressure sensor $(\mathrm{MKS})$ & $2 \%$ \\
\hline
\end{tabular}

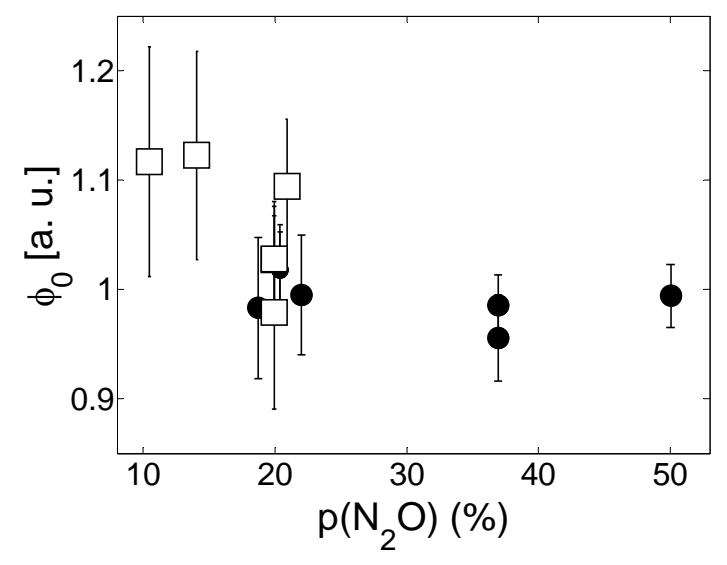

Fig. 6. Lamp flux measured with the $3 \mathrm{~mm}$ photolysis chamber (solid circles) and with the calibration tube with a 50 slm flow (open squares).

\subsubsection{Ground calibration}

The sensitivity of the LIF-FAGE instrument is influenced by the amount of water vapour and the pressure within the detection cell (Faloona et al., 2004). $\mathrm{H}_{2} \mathrm{O}$ as well as $\mathrm{N}_{2}$ and $\mathrm{O}_{2}$ reduce the fluorescence signal by collisional quenching of the excited states of $\mathrm{OH}$, which also depends on temperature. The temperature dependency of the population of the rovibronic states of the $\mathrm{OH}$ electronic ground state is calculated according to Dieke and Crosswhite (1962) and taken into account as well. The LIF signal $S$ is therefore a function of the laser light power $P$ in the detection cell, the water mixing ratio, the temperature $T$ and the density $\rho$.

The changing pressures at different altitude levels during the flights were simulated on the ground by applying various nozzle diameters $(0.7 \mathrm{~mm}$ to $1.5 \mathrm{~mm})$ to the inlet, producing pressures between 1.9 and $8.2 \mathrm{hPa}$ in the detection volume during calibration, fully covering the range of pressures of 2 to $5 \mathrm{hPa}$ registered during flights.

During the GABRIEL campaign, the influence of quenching was not sufficient to explain the sensitivity dependency on water mixing ratio, possibly due to wall loss effects on

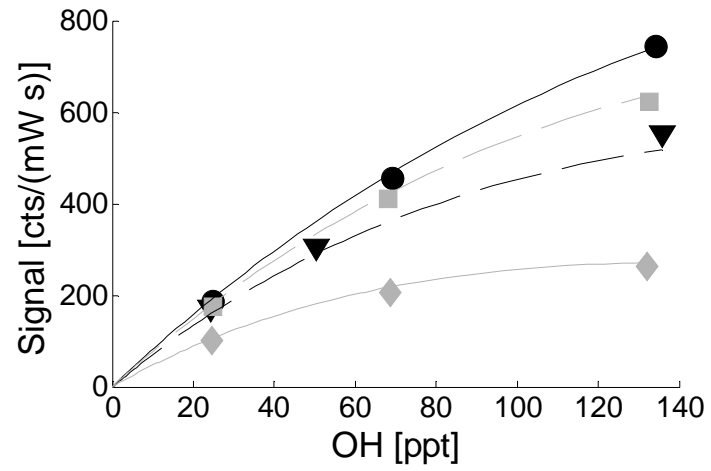

Fig. 7. Ground calibration performed during the campaign. Different $\mathrm{OH}$ concentrations were produced by irradiation of air with varying humidity, and the signal recorded at various internal pressures produced using different nozzle diameters (black circles at $2 \mathrm{hPa}$, grey squares at $3.1 \mathrm{hPa}$, black triangles at $4.6 \mathrm{hPa}$, diamonds at $8.3 \mathrm{hPa}$ ). The lines indicate the best fits using Eq. (4). The curvature is due to quenching with water.

the Teflon-coated inlet tube. The parameterization for the sensitivity dependencies characterized on the ground was improved by including additional dependencies on water mixing ratio in 1 st order and on density in 2 nd order:

$$
\begin{aligned}
& C\left(P, \mathrm{H}_{2} \mathrm{O}, T, \rho\right) \\
& \quad=C_{0} P\left[a_{0}+a_{1} \rho+a_{2} \rho^{2}\right]\left[1+a_{3} \mathrm{H}_{2} \mathrm{O}\right] Q\left(\rho, T, \mathrm{H}_{2} \mathrm{O}\right),
\end{aligned}
$$

where the parameters $C_{0}$, dependent on the optics and the detector sensitivity, and $a_{0}, a_{1}, a_{2}, a_{3}$ are determined from best fits to the ground calibration data. This parameterization may not be physically correct, but accurately describes the sensitivities observed.

The quenching factor $Q$ is given by Faloona et al. (2004)

$Q\left(\rho, T, \mathrm{H}_{2} \mathrm{O}\right)=\frac{1}{\Gamma}\left(e^{-\Gamma g_{1}}-e^{-\Gamma g_{2}}\right)$,

where $\Gamma\left(\rho, T, \mathrm{H}_{2} \mathrm{O}\right)$ is the excited state decay frequency, and $g_{1}$ and $g_{2}$ are the detector gate opening and closure times after excitation by the laser pulse, set to $164 \mathrm{~ns}$ and $600 \mathrm{~ns}$, respectively, during the GABRIEL campaign.

Ground calibrations were performed after each flight, an example of which is shown in Fig. 7. The major part of the nonlinearity in Fig. 7 is caused by quenching of the excited $\mathrm{OH}$ with $\mathrm{H}_{2} \mathrm{O}$ and is taken into account by the quenching factor $Q$. The change in sensitivity due to the additional water effect on sensitivity not due to quenching $\left(a_{3} \cdot \mathrm{H}_{2} \mathrm{O}\right.$ in Eq. 4) was a drop of $15 \%$ for $\mathrm{OH}$ and $20 \%$ for $\mathrm{HO}_{2}$ in sensitivity for water mixing ratios of $2.5 \%$ found at the lowest altitudes compared to dry air. The drop due to quenching is about double this amount.

The dependencies on density, temperature and humidity are expected to remain constant throughout the campaign, thus the parameters $a_{0}-a_{3}$ were the same for all calibrations performed. The parameter $C_{0}$, however, was allowed to vary 

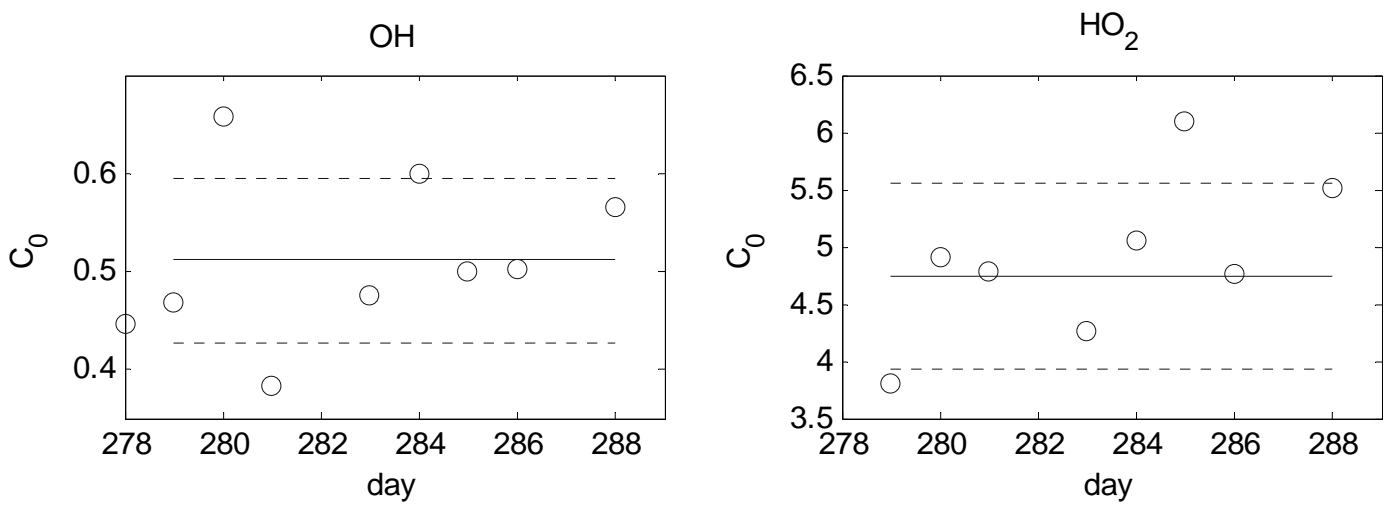

Fig. 8. Parameters $C_{0}$ derived from ground calibrations during the campaign. The time is indicated as Julian day, the solid line shows the mean value and the dashed lines the $1 \sigma$ standard deviation.

for each calibration due to problems with the pump setup during GABRIEL, which occasionally led to contamination of the optical components with rotary pump oil vapour during shutdown of the instrument. The resulting sensitivity coefficients for each flight day are plotted in Fig. 8. The sensitivity for $\mathrm{HO}_{2}$ was about a factor 3 lower than for $\mathrm{OH}$ due the combined effect of higher laser power used in the $\mathrm{OH}$ detection cell and lower wall loss of $\mathrm{HO}_{2}$.

The $1 \sigma$ uncertainty for $\mathrm{OH}$ and $\mathrm{HO}_{2}$ resulting from the density dependency was $6 \%$ and $9 \%$, for the water dependency $5 \%$ and $7 \%$, whereas the standard deviation of $C_{0}$ is $16 \%$ and $17 \%$, respectively. The error of the quenching factor Q was negligible as long as humidity data were available. When they were not (58\% of the data, including all of flights \#2 and \#7), the mean atmospheric absolute humidity profile observed during the GABRIEL campaign was used instead, leading to an additional systematic error of $2.6 \%$ on average and always below $7 \%$ for all data involved.

\subsubsection{In-flight calibration}

The calibration during flight complements the more timeintensive ground calibration, checking the dependencies found on the ground against sensitivity changes during flight. For instance, the ground calibration at different internal pressures is based on the assumption that the heterogeneous loss of $\mathrm{OH}$ or $\mathrm{HO}_{2}$ on the surface of the nozzle during entry is not a function of size. The validity of this assumption can be checked with the in-flight calibration, as well as temperature dependencies, which are otherwise solely based on calculations. Like the ground calibration, the in-flight calibration is based on photolysis of atmospheric water vapour, and the $\mathrm{OH}$-concentration produced during the in-flight calibrations is a function of the photon flux, the water concentration and the air speed (see Eq. 1). The ground calibrations during GABRIEL were made using $\mathrm{HO}_{\mathrm{x}}$ concentrations close to ambient $\mathrm{HO}_{2}$ concentrations but 2 orders of magnitude higher than ambient $\mathrm{OH}$ concentrations. The concentrations during in-flight calibrations were considerably lower, though still more than an order of magnitude higher than ambient $\mathrm{OH}$.

Whereas a relative calibration is sufficient for the purpose of in-flight calibration, a detailed knowledge of the lamp flux field from the Hg lamp installed in the shrouded inlet and the speed in the irradiated area is not necessary and only relative changes during the flight are monitored.

Due to technical problems with the phototubes it was not possible to monitor the photon flux from the lamp during the GABRIEL campaign, and we assume the intensity was constant throughout the campaign. This is reasonable since the lamp was heated and remained at $(20 \pm 10)^{\circ} \mathrm{C}$ during the flights.

The air speed in the area irradiated by the lamp is not the same as measured by the Pitot tube behind the instrument nozzle, but the ratio of these two air speeds should be constant at all speeds and altitude levels and even at all pitch angles flown. This assumption is supported by air flow simulations (Fig. 2). Calibrations were performed while the aircraft was flying straight at constant flight levels.

The atmospheric water vapour concentration was measured with the FABLE instrument (Fast AirBorne Licor Experiment, NDIR absorption spectrometer; Gurk et al., 2008).

$\mathrm{OH}$ was produced during calibration periods of about $2 \mathrm{~min}$, in concentrations typically higher than ambient by more than an order of magnitude, so the variability of the calibration signal due to changes in ambient $\mathrm{OH}$ was negligible. This was not the case for $\mathrm{HO}_{2}$, which is usually a factor 10 to 100 higher than $\mathrm{OH}$ in the troposphere, whereas the lamp produces equal amounts of $\mathrm{OH}$ and $\mathrm{HO}_{2}$. The $\mathrm{HO}_{2}$ produced during calibration was always less than atmospheric $\mathrm{HO}_{2}$ and comparable in magnitude to its natural variability during the calibration period. Therefore the in-flight calibration was used only to characterize the $\mathrm{OH}$ sensitivity of the instrument.

$\mathrm{OH}$ signals observed during the in-flight calibration are evaluated using the sensitivity calculated according to the 


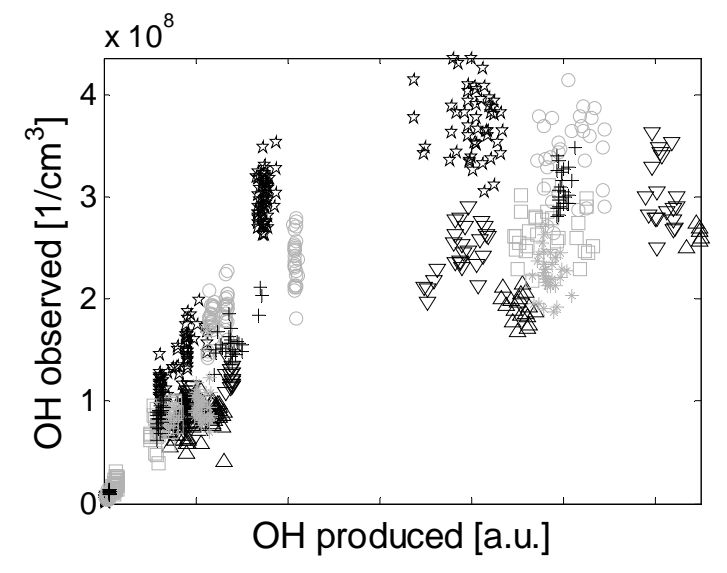

Fig. 9. In-flight calibrations (different symbols for each flight) evaluated according to the sensitivities derived from ground calibrations.

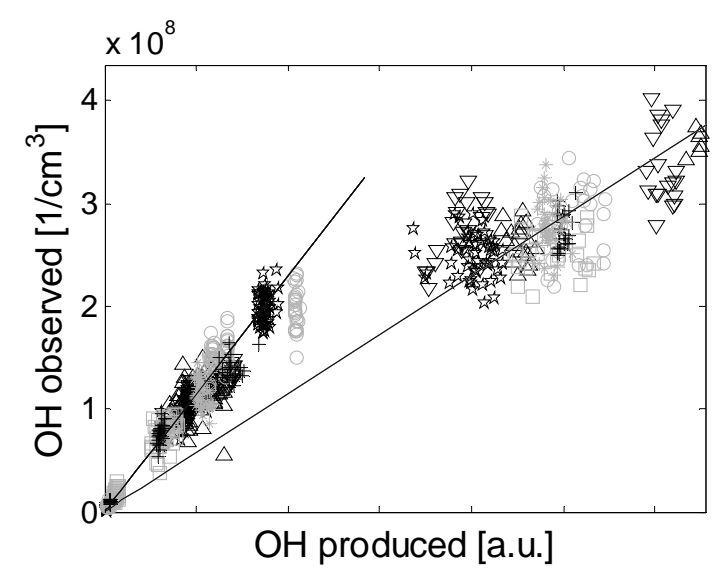

Fig. 10. In-flight calibrations (different symbols for each flight). Each flight was evaluated using the sensitivities derived from ground calibrations corrected by a constant factor for each flight in order to achieve best agreement of all flights. Seemingly two different sensitivity regimes exist, with higher sensitivity in conditions where less $\mathrm{OH}$ is produced by the in-flight calibrator, which is the case at higher altitudes due to lower ambient humidities.

ground calibration and compared to the $\mathrm{OH}$ concentrations produced. Figure 9 presents the results for all in-flight calibrations of the entire campaign, which show considerable scatter. However, the scatter is not random, but follows different slopes during individual flights. The most likely explanation is contamination of the optical components with oil vapour, which occasionally occurred during shutdown, changing the instrument sensitivity constant $C_{0}$ between the flight and the ground calibration performed afterwards. The in-flight calibrations can thus be used to derive correction factors for the ground calibrations. Application of these correction factors bring the in-flight calibrations into agreement by modifying the slope derived from all calibrations of each flight to an average slope of all calibrations performed during the campaign.
Table 2. Precision and accuracy $(1 \sigma)$ of the $\mathrm{HO}_{\mathrm{x}}$ measurements during GABRIEL.

\begin{tabular}{lcc}
\hline $1 \sigma$ & $\mathrm{OH}$ & $\mathrm{HO}_{2}$ \\
\hline $\begin{array}{l}\text { Precision } \\
\text { Accuracy }\end{array}$ & $7 \%$ & $1 \%$ \\
$\begin{array}{l}\text { All data except flights \#2 and \#7 } \\
\text { Flights \#2 and \#7 }\end{array}$ & $20 \%$ & $30 \%$ \\
$\begin{array}{l}\text { Possible maximum under-estimation in } \\
\text { the BL (or over-estimation in the FT) }\end{array}$ & $50 \%$ & $50 \%$ \\
\hline
\end{tabular}

$C_{0}^{*}=\frac{m_{i}}{\bar{m}} C_{0}$

For $\mathrm{HO}_{2}$ the ground calibration parameters were used without correction, as the in-flight calibrations were not adequate for $\mathrm{HO}_{2}$. The same holds for $\mathrm{OH}$ measured on flights \#2 and \#7, as no $\mathrm{H}_{2} \mathrm{O}$ data is available for these flights and the in-flight calibrations could therefore not be evaluated.

The $1 \sigma$ standard deviation of the corrected sensitivity constants $C_{0}^{*}$ for $\mathrm{OH}$ is $12 \%$. The variability of the correction factors $m_{i}$ is much larger: $26 \%$. The latter value is used as an error estimate for the sensitivity constant $C_{0}$ for $\mathrm{HO}_{2}$ and for $\mathrm{OH}$ during flights \#2 and \#7, when in-flight calibration was not available. Together with the uncertainties for the sensitivity dependencies on density, humidity and quenching discussed above, this leads to a total accuracy of our measurements $(1 \sigma)$ of approximately $20 \%$ for $\mathrm{OH}$ for all data except for flights \#2 and \#7, and $60 \%$ for $\mathrm{OH}$ on these flights and for the $\mathrm{HO}_{2}$ data. The overall precision and accuracy of the $\mathrm{HO}_{\mathrm{x}}$ measurements during GABRIEL is summarized in Table 2.

The in-flight calibrations with the corrected sensitivity constants $C_{0}^{*}$ are shown in Fig. 10. Two different regimes are now apparent, with higher sensitivity in conditions where less $\mathrm{OH}$ is produced by the in-flight calibrator, which is the case at higher altitudes due to lower ambient humidity. The two sensitivity regimes separate conditions which differ in altitude (below and above $2000 \mathrm{~m}$ a.s.1.), ambient water mixing ratio (above and below 1.5\%), ambient pressure and temperature, and atmospheric layer (boundary layer and free troposphere). The instrument sensitivity appears to be almost twice as high in the free troposphere compared to the boundary layer. We cannot discern if the reason is indeed a change in instrument sensitivity either not characterized or incorrectly characterized by the ground calibration, or an underestimation of the $\mathrm{OH}$ produced during calibration at higher altitudes, e.g. due to variations in lamp flux or condensation on the windows, or an overestimation at lower altitudes. If the discrepancy is due to an under- or overestimation of the $\mathrm{OH}$ produced during calibrations and not to a real change in instrument sensitivity, our evaluation is correct. If instead there is a real change in instrument sensitivity not characterized by 

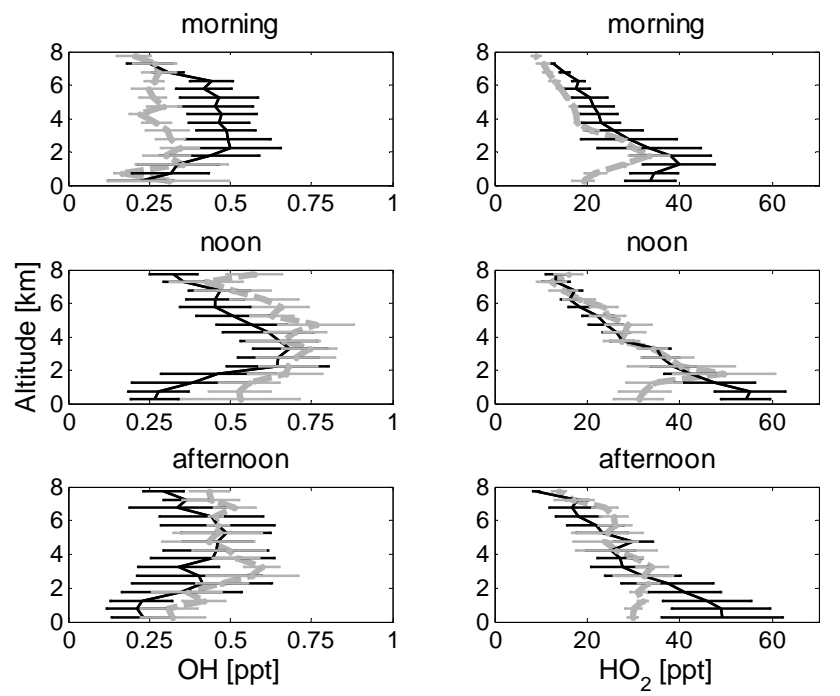

Fig. 11. Average profiles of $\mathrm{OH}$ and $\mathrm{HO}_{2}$ mixing ratios over the ocean (grey dashed lines) and over the forest (black solid lines) measured in the morning (08:00-11:00 LT), around noon (11:0014:00 LT) and in the afternoon (14:00-17:00 LT).

the ground calibration, we either overestimate $\mathrm{OH}$ and possibly also $\mathrm{HO}_{2}$ in the free troposphere (if the ground calibration is more representative for the sensitivity in the boundary layer) and/or underestimate them in the boundary layer by up to a factor 2 .

\subsubsection{Interferences}

Likely interferences from compounds either fluorescing at similar wavelengths as $\mathrm{OH}$ or producing $\mathrm{OH}$ within the instrument have been examined in detail for the Penn-State ATHOS instrument, on which the detection unit of our HORUS instrument is based (Ren et al., 2004). Beside a negative interference from naphthalene, no significant interference was found for any of the examined compounds at atmospheric mixing ratios, including ozone, hydrogen peroxide, formaldehyde, sulfur dioxide, nitrous acid, nitric acid, organic peroxy radicals and various VOC including isoprene.

\section{Results and discussion}

\section{1 $\mathrm{HO}_{\mathrm{x}}$ mixing ratios, diurnal variation and spatial distribution}

$\mathrm{OH}$ and $\mathrm{HO}_{2}$ were measured during all flights starting from flight \#2. Over the forest and especially in the boundary layer a strong influence from biogenic hydrocarbon emissions such as isoprene was expected. Most of these hydrocarbons are emitted in reduced forms containing one or more double bonds and hence should react rapidly with $\mathrm{OH}$. Under low$\mathrm{NO}_{\mathrm{x}}$ conditions, the main sink for $\mathrm{HO}_{2}$ is the reaction with
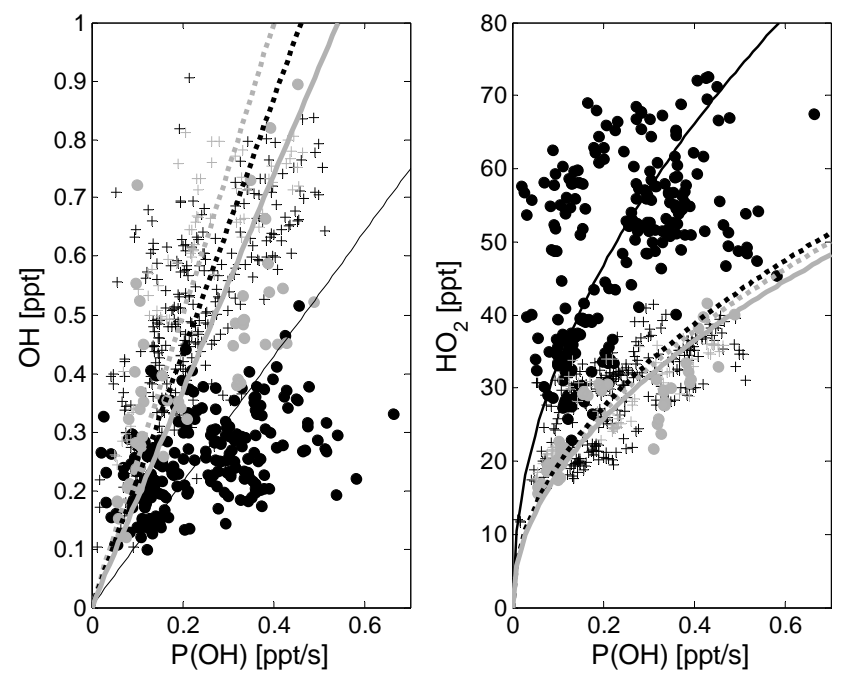

Fig. 12. Mixing ratios of $\mathrm{OH}$ and $\mathrm{HO}_{2}$ as a function of $\mathrm{OH}$ production from photolysis of $\mathrm{O}_{3}$ in the free troposphere between 3000 and $5000 \mathrm{~m}$ a.s.l. (crosses, dotted lines) and below $1000 \mathrm{~m}$ a.s.l. (solid circles, solid lines) over the forest (black) and over the ocean (grey).

peroxy radicals, and hydrocarbon oxidation enhances peroxy radical formation. Therefore model calculations generally predict very low $\mathrm{OH}$ and $\mathrm{HO}_{2}$ mixing ratios in the boundary layer over large rainforest areas (Poisson et al., 2000; von Kuhlmann et al., 2004; Lelieveld et al., 2008).

Forest emissions of hydrocarbons have previously been shown to be both temperature and light dependent (Guenther et al., 1995). Therefore the VOC composition over the forest is likely to vary with the time of day. To study the influence of forest emissions on the $\mathrm{HO}_{\mathrm{x}}$ budget, all data was binned for morning, noon and afternoon hours, separately for measurements over the forest and over the ocean. The "morning" dataset includes all measurements between 08:00 and 11:00 local time (UTC-3 h), "noon" between 11:00 and 14:00, and "afternoon" between 14:00 and 17:00. All data for which topographical elevation is absent $(0 \mathrm{~m}$ a.s.1.) is considered to be over the ocean, whereas data taken west of $52^{\circ} 30^{\prime} \mathrm{W}$ and south of $5^{\circ} 39^{\prime} \mathrm{S}$ is considered to be over the forest (see map in Fig. 14); data measured between the coastline and the forest data boundaries, amounting to about $9 \%$ of all data, was not taken into account.

$\mathrm{OH}$ mixing ratios varied between $0.25 \mathrm{ppt}$ in the morning and up to $0.75 \mathrm{ppt}$ around noon, when photolytic production is highest (Fig. 11). Maximum mixing ratios of $\mathrm{OH}$ were encountered at about 2 to $3 \mathrm{~km}$ altitude a.s.1., decreasing towards higher altitudes and in the boundary layer. The decrease in the boundary layer is strongest over the forest around noon, where on average $0.25 \mathrm{ppt}$ were observed at $500 \mathrm{~m}$ a.s.l. over the forest, compared to $0.5 \mathrm{ppt}$ at the same altitude over the ocean. However, the mixing ratios encountered over the forest canopy were still much higher than predicted by chemical transport and box models, which typically 

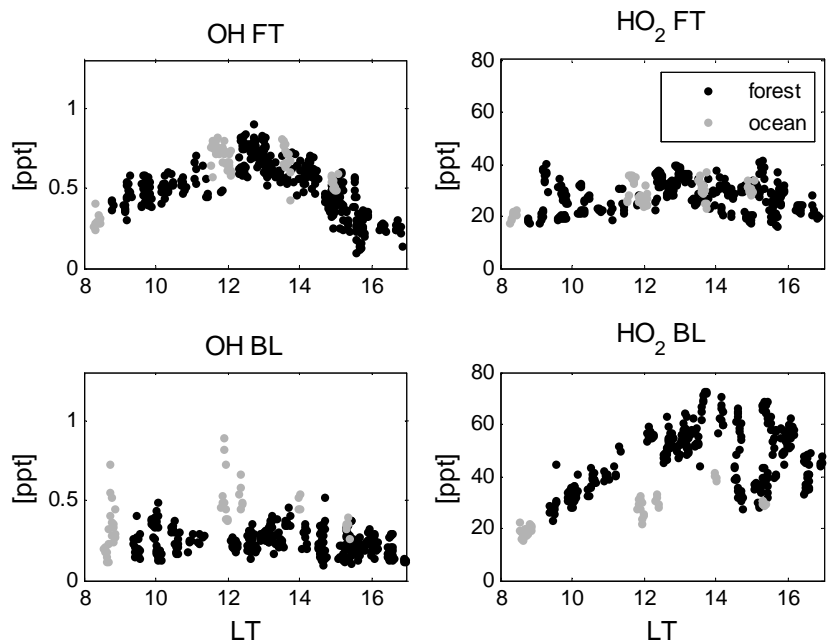

Fig. 13. Diurnal variation of $\mathrm{OH}$ (1 min data) and $\mathrm{HO}_{2}$ (10 s data) between 3000 and $5000 \mathrm{~m}$ a.s.l. (free troposphere, FT) and below $1000 \mathrm{~m}$ a.s.l. (boundary layer, BL) over the forest (black) and over the ocean (grey).

calculate less than $10^{6}$ molecules $/ \mathrm{cm}^{3}$ or $0.04 \mathrm{ppt} \mathrm{OH}$ in the boundary layer (Lelieveld et al., 2008; Butler et al., 2008; Kubistin et al., 2008).

The $\mathrm{HO}_{2}$ vertical profiles observed over the ocean and over the forest were quite similar in the free troposphere, showing decreasing mixing ratios with increasing altitude above 2 to $3 \mathrm{~km}$ a.s.l., and reaching up to $40 \mathrm{ppt}$ at $2 \mathrm{~km}$ a.s.l. (Fig. 11). In the boundary layer the picture is rather different: whereas over the ocean $\mathrm{HO}_{2}$ increases with altitude together with $\mathrm{OH}$, over the forest $\mathrm{HO}_{2}$ is significantly more abundant. $\mathrm{HO}_{2}$ in the forest boundary layer accordingly increases only slightly with increasing altitude in the morning. At noon, average mixing ratios of $55 \mathrm{ppt}$ were observed at the lowest flight levels, and somewhat lower mixing ratios of around $50 \mathrm{ppt}$ in the afternoon, decreasing with altitude. Contrasting with these observations, models compute lower $\mathrm{HO}_{2}$ over the rain forest than over the ocean (Ganzeveld et al., 2008; Butler et al., 2008; Kubistin et al., 2008).

The main primary source of $\mathrm{HO}_{\mathrm{x}}$ is the photolysis of ozone and subsequent reaction with water. More clouds over the continent lead to somewhat lower $\mathrm{J}\left(\mathrm{O}^{1} \mathrm{D}\right)$ values: $6.3 \times 10^{-5} \mathrm{~s}^{-1}$ in average compared to $7.5 \times 10^{-5} \mathrm{~s}^{-1}$ over the ocean for noontime data. $\mathrm{OH}$ production from $\mathrm{O}_{3}$ photolysis however was very comparable $(0.36 \mathrm{ppt} / \mathrm{s})$, because the lower $\mathrm{J}$-values were compensated by somewhat higher $\mathrm{O}_{3}$ over the forest (18.5 ppb compared to $14.7 \mathrm{ppb}$ over the ocean).

$\mathrm{Te}$ photolytic source strength of $\mathrm{HO}_{\mathrm{x}}$ varies strongly throughout the day mainly due to changing photolysis rates. If the sinks of $\mathrm{OH}$ are less variable, which is usually the case in the absence of variable local emissions, a linear correlation of $\mathrm{OH}$ with the $\mathrm{OH}$ production rate from ozone photolysis is expected (Holland et al., 2003). In environments with low concentrations of $\mathrm{NO}$, the cycling of $\mathrm{HO}_{2}$ to $\mathrm{OH}$ is limited. The dominant sink of $\mathrm{HO}_{2}$ under these conditions is the selfreaction and the reaction with organic peroxy radicals. The main sink is therefore proportional to the square of the $\mathrm{HO}_{2}$ concentration, leading to a correlation between $\mathrm{HO}_{2}$ and the square root of the production rate (Penkett et al., 1997; Bloss et al, 2007).

$\mathrm{OH}$ concentrations observed in the free troposphere between 3000 and $5000 \mathrm{~m}$ a.s.l. both over the ocean and over the forest and in the boundary layer over the ocean all show the expected linear correlation (Fig. 12). By plotting mixing ratios rather than concentrations versus production rates, the slopes are comparable despite the different altitude ranges. The $\mathrm{OH}$ mixing ratio in the boundary layer over the forest shows only a weak correlation with the $\mathrm{OH}$ production rate $\left(R^{2}=0.19\right)$, compared to $R^{2}=0.69,0.47$ and 0.48 in the free troposphere over the ocean and over the forest and in the boundary layer over the ocean, respectively. For $\mathrm{HO}_{2}$ the correlation with the square root of the $\mathrm{OH}$ production rate is also lower in the boundary layer over the forest, with $R^{2}=0.24$ compared to $0.59,0.53$ and 0.76 in the free troposphere over the ocean and over the forest and in the boundary layer over the ocean, respectively (Fig. 12).

A strong dependency of $\mathrm{OH}$ and $\mathrm{HO}_{2}$ on the time of day is also to be expected. Indeed, the highest mixing ratios of about $0.7 \mathrm{ppt} \mathrm{OH}$ were found around 12:30 local time in the free troposphere, independent of location (Fig. 13). This diurnal variation, however, was absent in the boundary layer over the forest, where observed mixing ratios scattered around 0.1 to $0.5 \mathrm{ppt}$ throughout the day with no discernible temporal dependency. In contrast, the daytime maximum of $\mathrm{HO}_{2}$ in the forest boundary layer, which is reached later in the afternoon at around 14:00 LT, was enhanced by about a factor 2 in the forest boundary layer compared to that over the ocean.

Thus our measurements show that, when an air parcel is transported through the boundary layer over the rainforest and entrains biogenic emissions, $\mathrm{OH}$ decreases whereas $\mathrm{HO}_{2}$ increases. The VOC emissions from the rainforest as well as their photochemical products can be expected to affect the $\mathrm{HO}_{\mathrm{x}}$ mixing ratios. If the hydrocarbon emissions and their secondary products accumulate in the air as it is being transported over the forest, then $\mathrm{HO}_{\mathrm{x}}$ mixing ratios measured at the same time of day should change consistently with distance from the coast. However, no such trend is discernible from our data. Instead the coastline quite clearly separates the two concentration regimes: $\mathrm{OH}$ decreases and $\mathrm{HO}_{2}$ increases abruptly at the coastline (Fig. 14), and VOC accumulation either does not occur or has no significant photochemical consequencies. The data rather suggests that the VOC emissions mixed into the boundary layer instantaneously affect $\mathrm{HO}_{\mathrm{x}}$. This indicates that the compounds influencing $\mathrm{HO}_{\mathrm{x}}$ are relatively short-lived, with a lifetime of the order of the boundary layer mixing time scale, which is about an hour or less (Eerdekens et al., 2009; Ganzeveld et al., 2008). 

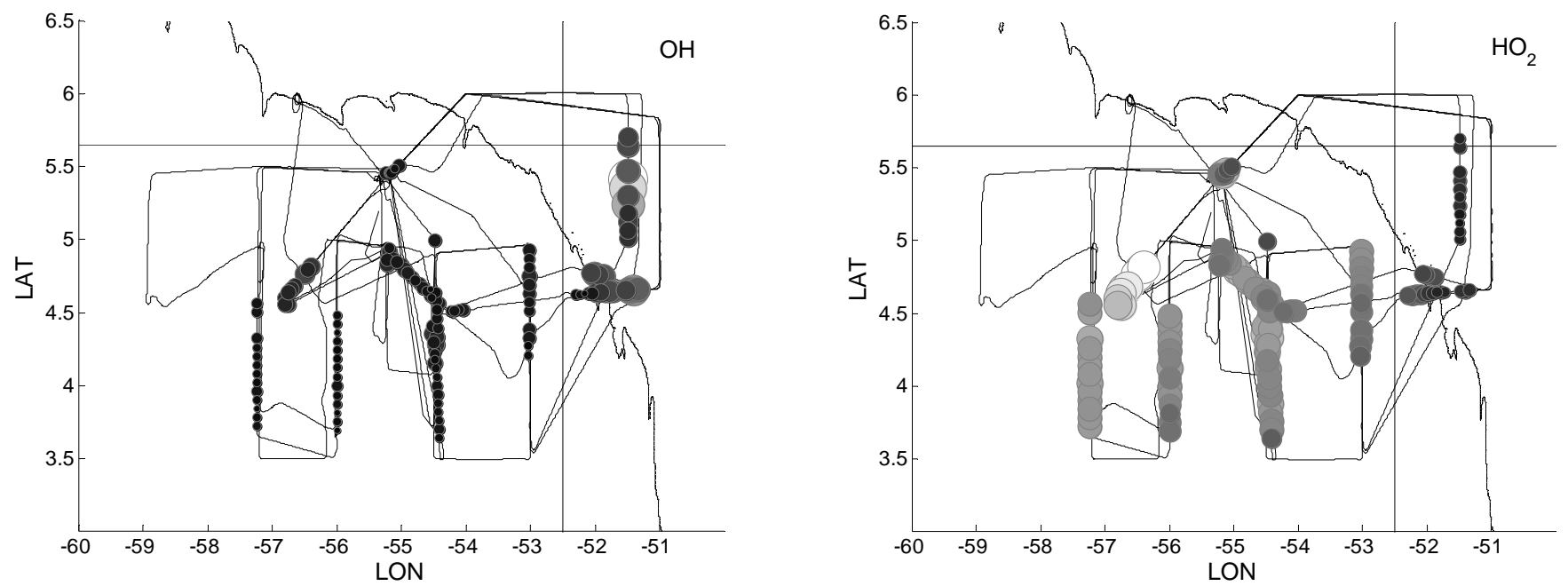

Fig. 14. Geographical distribution of $\mathrm{OH}$ (left panel) and $\mathrm{HO}_{2}$ (right panel) in the lowest $1000 \mathrm{~m}$ a.s.l. measured around noon (11:0014:00 LT). Mixing ratios are represented by circle diameters as well as shade (lighter for higher mixing ratios). The location of the coastline and the flight tracks are also shown (black lines).

\section{2 $\mathrm{HO}_{\mathrm{x}}$ sources}

$\mathrm{O}_{3}$, NO, $\mathrm{HCHO}$, the sum of $\mathrm{H}_{2} \mathrm{O}_{2}$ and organic peroxides and the photolysis frequency of $\mathrm{NO}_{2}$ were all measured during the GABRIEL campaign (Stickler et al., 2007). Other photolysis frequencies apart from $J_{\mathrm{NO} 2}$ were calculated with the radiative transport model TUV v4.1 (Tropospheric Ultraviolet-Visible Model; Madronich and Flocke, 1998) and scaled to the ratio of measured to calculated $\mathrm{NO}_{2}$ photolysis frequencies.

Thus the main sources of $\mathrm{OH}$ can be calculated from the measured data. Since only the sum of peroxides was measured, photolysis of organic peroxides was considered in the calculation assuming production of $2 \mathrm{OH}$ radicals, yielding an upper limit. The dominant $\mathrm{OH}$ source in the troposphere up to $6 \mathrm{~km}$ a.s.l. is the photolysis of ozone and the reaction of $\mathrm{O}\left({ }^{1} \mathrm{D}\right)$ with water (Fig. 15). At higheemr altitudes and lower humidity the photolysis of peroxides becomes more important. Conversion of $\mathrm{HO}_{2}$ to $\mathrm{OH}$ through reactions with $\mathrm{NO}$ and $\mathrm{O}_{3}$ also contribute substantially in the upper troposphere, and in the morning also in the boundary layer.

Most of the primary $\mathrm{HO}_{\mathrm{x}}$ production is production of $\mathrm{OH}$, amounting to up to $2 \times 10^{7}$ molecules $/ \mathrm{cm}^{3} / \mathrm{s}$. Production of $\mathrm{HO}_{2}$ from photolysis of formaldehyde is much less amounting up to $3 \times 10^{6}$ molecules $/ \mathrm{cm}^{3} / \mathrm{s}$.

The source terms are actually quite similar when comparing air over the forest and over the ocean. Only the conversion of $\mathrm{HO}_{2}$ to $\mathrm{OH}$ through reaction with $\mathrm{NO}$ is more important over the forest, mostly due to $\mathrm{NO}$ emissions from the soil (Ganzeveld et al., 2008). OH production due to $\mathrm{O}_{3}$ photolysis decreases in the boundary layer mainly because ozone mixing ratios also decrease from $(40 \pm 10) \mathrm{ppb}$ at 2 to $3 \mathrm{~km}$ to $(17 \pm 4) \mathrm{ppb}$ within the lowest $1000 \mathrm{~m}$ a.s.l., with slightly higher values over the forest than over the ocean (Stickler et al., 2007). At higher altitudes the $\mathrm{OH}$ production rate decreases due to the declining absolute humidity.

\subsection{OH sinks}

The Learjet payload included measurements of the main reactants of $\mathrm{OH}$, including isoprene and the sum of its reaction products methacrolein (MACR) and methyl vinyl ketone (MVK). The $\mathrm{OH}$ reactivity, which is the inverse of the $\mathrm{OH}$ lifetime, can therefore be derived from the sum of the reaction rate coefficients times the measured reactant concentrations (for MVK+MACR the mean of their reactivities was used). The altitude profiles of the $\mathrm{OH}$ reactivity over the forest and over the ocean are compared in Fig. 16. Over the ocean isoprene, methacrolein and MVK are below the detection limit and the total reactivity is below $1 \mathrm{~s}^{-1}$, decreasing further at higher altitudes. $\mathrm{CO}$ is the main reactant with $\mathrm{OH}$ at all altitudes, contributing more than half of the total reactivity, followed by methane, formaldehyde and $\mathrm{O}_{3}$. Over the forest, these four species give rise to reactivities of up to $1.2 \mathrm{~s}^{-1}$ in the boundary layer, somewhat higher than over the ocean due to higher $\mathrm{CO}$ and formaldehyde mixing ratios (Stickler et al., 2007). The total calculated $\mathrm{OH}$ reactivity, however, is clearly dominated by isoprene, contributing about $75 \%$ of the total reactivity of 7 to $9 \mathrm{~s}^{-1}$ in the boundary layer. Other species not measured on the Learjet could contribute to increase this number, as indicated by very high total OH reactivities of the order of 100/s measured within the canopy during the GABRIEL campaign (Sinha et al., 2008). In the free troposphere, $\mathrm{OH}$ reactivities are similar over the forest and over the ocean. 

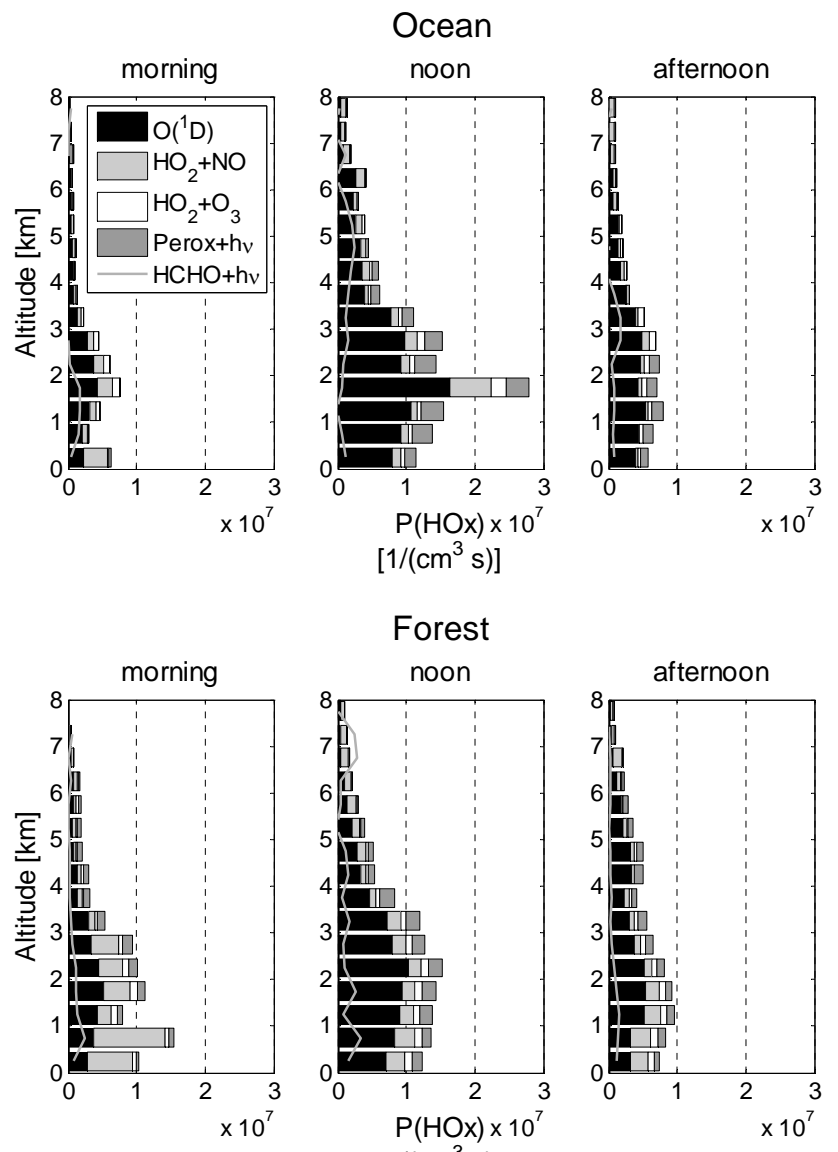

$\left[1 /\left(\mathrm{cm}^{3} \mathrm{~s}\right)\right]$

Fig. 15. Median profiles of the main $\mathrm{OH}$ production rates calculated from measured trace gas concentrations over the ocean (upper row) and over the forest (lower row) measured in the morning (07:00-11:00 LT), around noon (11:00-14:00 LT) and in the afternoon (14:00-17:00 LT). In addition, the production of $\mathrm{HO}_{2}$ via photolysis of formaldehyde is shown by the grey line.

\subsection{OH steady state}

According to the $\mathrm{OH}$ reactivities derived in the previous section, $\mathrm{OH}$ lifetimes vary between $0.1 \mathrm{~s}$ in the forest boundary layer and a few seconds in the upper troposphere. $\mathrm{OH}$ concentrations therefore adjust rapidly to changing conditions in an air mass reaching steady state, where $\mathrm{OH}$ production and destruction balance. Total $\mathrm{OH}$ destruction can be calculated from measured $\mathrm{OH}$ concentrations and reactivities and compared to the total production.

$\mathrm{OH}$ production and destruction generally agree within the uncertainty and the variability of the observations (Fig. 17). However, they differ significantly in the forest boundary layer at noon and in the afternoon. Here the $\mathrm{OH}$ destruction derived from trace gas observations strongly exceeds the production due to much higher sinks compared to the morning hours, whereas the sources do not change as much throughout the day. At noon and in the afternoon $\mathrm{OH}$ destruc-
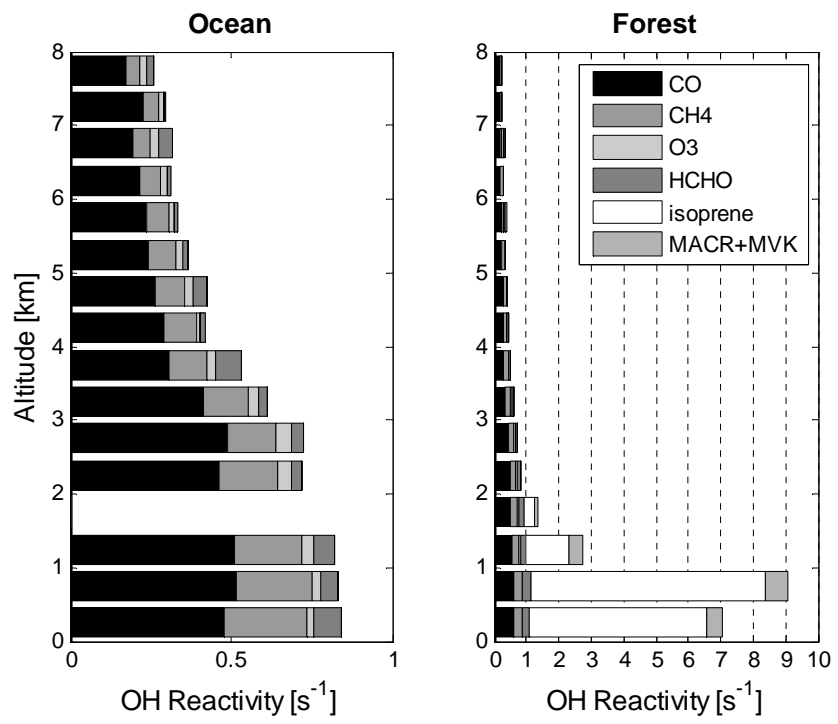

Fig. 16. Median profiles of the dominant reactions contributing to total $\mathrm{OH}$ loss, calculated from measured trace gas concentrations from the entire data set over the ocean (left panel) and over the forest (right panel), columns stacked in the order given in the legend.

\section{Ocean}

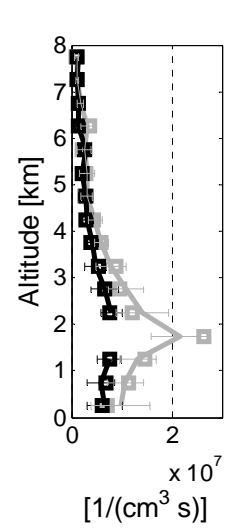

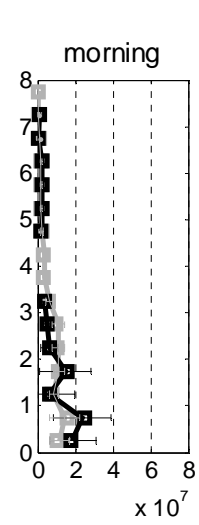

$\times 10^{7}$
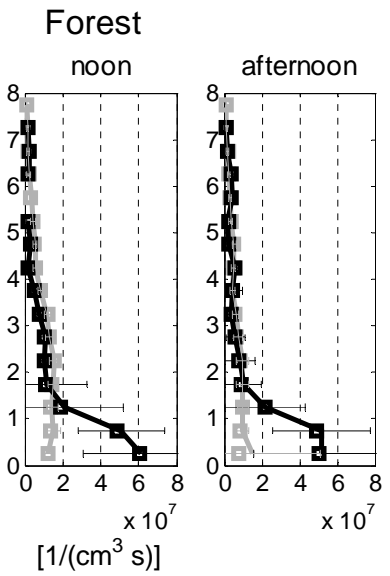

Fig. 17. Median profiles of $\mathrm{OH}$ production (grey) and destruction (black), over the ocean (all data) and over the forest at different times of day. The squares indicate the median values, the error bars the variability (standard deviation).

tion in the forest boundary layer based on measured trace gases is about $5 \times 10^{7}$ molecules $/ \mathrm{cm}^{3} / \mathrm{s}$, pointing towards additional unaccounted for production mechanisms which are about 4 times larger than the known $\mathrm{OH}$ sources. The missing production thus correlates with the main sinks, indicating additional $\mathrm{OH}$ recycling rather than primary sources. The most important sink of $\mathrm{OH}$ in the forest boundary layer, as shown in the previous section, is the reaction with isoprene. This compound is emitted by the vegetation depending on light and temperature (Guenther et al., 1991), and during the GABRIEL campaign isoprene concentrations were usually 


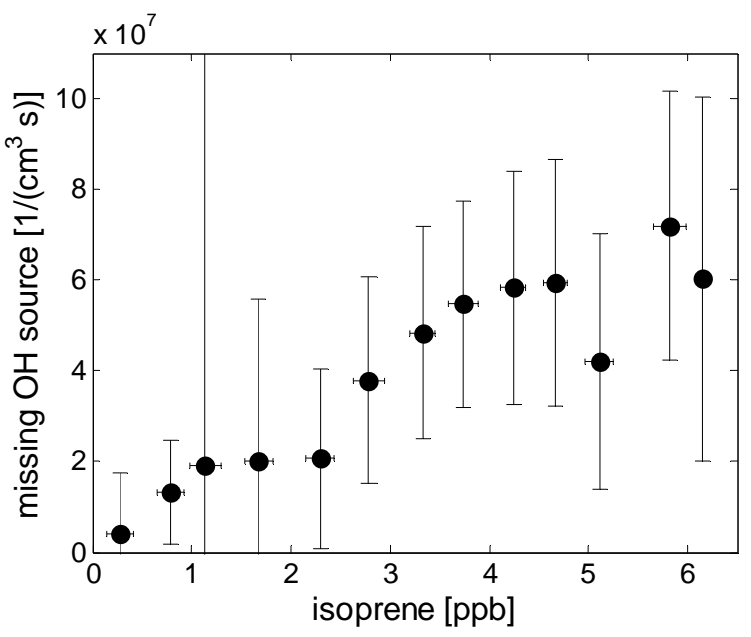

Fig. 18. Missing $\mathrm{OH}$ source as a function of isoprene, circles are median values, the error bars indicate the variability (standard deviation).

higher later in the day following the increase in temperature, showing a clear correlation with the missing $\mathrm{OH}$ source (Fig. 18). Additional recycling of $\mathrm{OH}$ related to isoprene chemistry is therefore most likely to resolve the discrepancy between $\mathrm{OH}$ production and destruction found during GABRIEL (see also Lelieveld et al., 2008).

\section{Conclusions}

While here we present the first $\mathrm{OH}$ measurements from the boundary layer over the pristine (low-NO) tropical rainforest, there is some previous experimental evidence which has suggested a higher oxidation capacity in the forested boundary layer than predicted by models. Carslaw et al. (2001) found $\mathrm{OH}$ measured in a forested region to be on average a factor 2 higher than could be reproduced by a box model, simulated $\mathrm{HO}_{2}$ however was sometimes too high by up to an order of magnitude. Observations by Tan et al. (2001) in a deciduous forest with low $\mathrm{NO}_{\mathrm{x}}$ and high isoprene emissions were a factor 2.7 in average higher than modelled, while $\mathrm{HO}_{2}$ was in good agreement. Thornton et al. (2002) suggested a reduction of the $\mathrm{HO}_{\mathrm{x}}$ chain termination reaction of $\mathrm{HO}_{2}$ with $\mathrm{RO}_{2}$ yielding $\mathrm{ROOH}$ by about a factor of 10 in order to explain measurements in Nashville, Tennessee, in a suburban environment with a high biogenic VOC load, where measured $\mathrm{OH}$ and $\mathrm{HO}_{2}$ were in average $36 \%$ and $55 \%$ higher than simulated by a constrained box-model (Martinez et al., 2003). Kuhn et al. (2007) indirectly inferred a range of $\mathrm{OH}$ concentrations during daytime of $3-8 \times 10^{6} \mathrm{~cm}^{-3}$ from vertical gradients of isoprene, methyl vinyl ketone and methacrolein in Brazil. Ren et al. (2008) measured OH over North America and found that the observed-to-modeled $\mathrm{OH}$ ratio in the planetary boundary layer in forested regions is a strong function of isoprene. Furthermore, atmospheric chemistry-transport models using isoprene emission inventories tend to strongly overestimate isoprene in the boundary layer over forests. To get around this problem, isoprene sources have been reduced in models by a factor of two or more (von Kuhlmann et al., 2004; Jöckel et al., 2006). OH mixing ratios higher than can be explained with current chemistry schemes could solve this discrepancy. The measurements presented here are the first direct evidence of a higher than predicted oxidation capacity over tropical rainforests and its link to the rainforest emissions of isoprene.

The possibility of a measurement error needs to be addressed. Likely interferences from other compounds present in the atmosphere have been examined in detail for the PennState ATHOS instrument, on which the detection unit of our HORUS instrument is based (Ren et al., 2004). Even though significant interferences can be excluded for many compounds, including isoprene, the possibility of interference from an unidentified compound present over the rainforest cannot be completely ruled out. The good agreement of measured $\mathrm{OH}$ with the expected steady state conditions over the ocean and in the free troposphere corroborates the absence of instrumental problems under a wide range of conditions, including temperature, humidity and pressure variations from the tropical boundary layer to the upper troposphere. Therefore any hypothetical interference would have to be related to a trace gas present only in the forest boundary layer. Furthermore, it should be emphasized that $\mathrm{HO}_{2}$ mixing ratios were also greatly enhanced over the rainforest, while models compute lower $\mathrm{HO}_{2}$ over the rain forest than over the ocean (Ganzeveld et al., 2008; Butler et al., 2008; Kubistin et al., 2008). As mixing ratios of $\mathrm{HO}_{2}$ are typically 2 orders of magnitude higher than $\mathrm{OH}$, an interference for $\mathrm{HO}_{2}$ as well as for $\mathrm{OH}$ would require the $\mathrm{OH}$ interference signal to be enhanced by 2 orders of magnitude when the sampled air is mixed with high concentrations of NO in the instrument for conversion of $\mathrm{HO}_{2}$ to $\mathrm{OH}$.

The total $\mathrm{OH}$ reactivity derived in this work is based on the limited set of hydrocarbon measurements on the Learjet. Other hydrocarbon species emitted by the forest but not measured are likely to further increase the total $\mathrm{OH}$ reactivity, e.g. the monoterpenes (DiCarlo et al., 2004; Williams et al., 2007). Measurements of total $\mathrm{OH}$ reactivity were not performed on the Learjet, although a limited dataset is available from within the canopy on Brownsberg, a ground site close to our operational base in central Suriname (Sinha et al., 2008). These measurements show very high reactivities, of the order of $100 \mathrm{~s}^{-1}$. It may be speculated that within the canopy a large variety of hydrocarbons emitted by the rainforest is present, including e.g. sesquiterpenes, many of which are highly reactive and therefore short-lived. These species are unlikely to survive long enough to play a significant role even at the lowest altitudes sampled with the Learjet (around $300 \mathrm{~m}$ a.s.1.), though they could be important for $\mathrm{HO}_{\mathrm{x}}$ concentrations within the canopy, possibly providing 
an $\mathrm{OH}$ source through ozonolysis as well as an $\mathrm{OH}$ sink. Measurements of $\mathrm{HO}_{\mathrm{x}}$ and $\mathrm{OH}$ reactivity within the rainforest canopy will be crucial to unravel the intriguing atmospheric chemistry of the rainforest ecosystem.

Missing $\mathrm{OH}$ production has been found to be about 4 times larger than the sum of known $\mathrm{OH}$ sources in the rainforest boundary layer and to correlate with isoprene emissions. While the existence of primary sources, e.g. ozonolysis of reactive hydrocarbons emitted together with isoprene, cannot be ruled out, the possibility of unknown reactions recycling $\mathrm{OH}$ at some intermediate step of isoprene chemistry is a more straightforward explanation. This hypothesis is further discussed in other papers of the GABRIEL special issue through comparison of the measurements presented here with the results of a box model (Kubistin et al., 2008) and of a global chemistry-climate model (Butler et al., 2008).

Acknowledgements. The first deployment of our instrument on aircraft would not have been possible without the invaluable support provided by Enviscope GmbH (Frankfurt, Germany) and the technicians of the GFD (Gesellschaft für Flugzieldarstellung, Hohn, Germany) during integration into the Learjet, the conduction of test-flights prior to and during the GABRIEL campaign. We also wish to thank the pilots of the GFD for their engagement in the design of unconventional flight plans and their realization. Further, we thank Tim Butler and Mark Lawrence for their contribution in planning the flight tracks during the campaign using chemical weather forecasts, as well as helpful discussions on the results of global model simulations.

The service charges for this open access publication have been covered by the Max Planck Society.

Edited by: R. Cohen

\section{References}

Bloss, W. J., Lee, J. D., Heard, D. E., Salmon, R. A., Bauguitte, S. J.-B., Roscoe, H. K., and Jones, A. E.: Observations of OH and $\mathrm{HO}_{2}$ radicals in coastal Antarctica, Atmos. Chem. Phys., 7, 4171-4185, 2007,

http://www.atmos-chem-phys.net/7/4171/2007/.

Butler, T. M., Taraborrelli, D., Brühl, C., Fischer, H., Harder, H., Martinez, M., Williams, J., Lawrence, M. G., and Lelieveld, J.: Improved simulation of isoprene oxidation chemistry with the ECHAM5/MESSy chemistry-climate model: lessons from the GABRIEL airborne field campaign, Atmos. Chem. Phys., 8, 4529-4546, 2008, http://www.atmos-chem-phys.net/8/4529/2008/.

Cantrell, C. A., Tyndall, G., and Zimmer, A.: Absorption cross sections for water vapor from 183 to $193 \mathrm{~nm}$, Geophys. Res. Lett., 24, 2195-2198, 1997.

Carslaw, N., Creasey, D. J., Harrison, D., Heard, D. E., Hunter, M. C., Jacobs, P. J., Jenkin, M. E., Lee, J. D., Lewis, A. C., Pilling, M. J., Saunders, S. M., and Seakins, P. W.: $\mathrm{OH}$ and $\mathrm{HO}_{2}$ radical chemistry in a forested region of north-western Greece, Atmos. Environ., 35, 4725-4737, 2001.

Creasey, D. J., Heard, D. E., and Lee, J. D.: Absorption crosssection measurements of water vapour and oxygen at $185 \mathrm{~nm}$.
Implications for the calibration of field instruments to measure $\mathrm{OH}, \mathrm{HO}_{2}$ and $\mathrm{RO}_{2}$ radicals, Geophys. Res. Lett., 27, 1651-1654, 2000.

Di Carlo, P., Brune, W. H., Martinez, M., Harder, H., Lesher, R., Ren, X., Thornberry, T., Carroll, M. A., Young, V., Shepson, P. B., Riemer, D., Apel, E., and Campbell, C.: Missing OH reactivity in a forest: Evidence for unknown reactive biogenic VOCs, Science, 304, 722-725, 2004.

Edwards, G. D., Cantrell, A. C., Stephens, S., Hill, B., Goyea, O., Shetter, R. E., Mauldin, R. L., Kosciuch, E., Tanner, D., and Eisele, F. L.: Chemical ionization mass spectrometer instrument for the measurement of tropospheric $\mathrm{HO}_{2}$ and $\mathrm{RO}_{2}$, Anal. Chem., 75, 5312-5327, 2003.

Eerdekens, G., Ganzeveld, L., Vilà-Guerau de Arellano, J., Klüpfel, T., Sinha, V., Yassaa, N., Williams, J., Harder, H., Kubistin, D., Martinez, M., and Lelieveld, J.: Flux estimates of isoprene, methanol and acetone from airborne PTR-MS measurements over the tropical rainforest during the GABRIEL 2005 campaign, Atmos. Chem. Phys., 9, 4207-4227, 2009, http://www.atmos-chem-phys.net/9/4207/2009/.

Eisele, F. L., Mauldin III, R. L., Tanner, D. J., Fox, J. R., Mouch, T., and Scully, T.: An inlet/sampling duct for airborne $\mathrm{OH}$ and sulfuric acid measurements, J. Geophys. Res., 102, 27993-28001, 1997.

Faloona, I. C., Tan, D., Lesher, R. L., Hazen, N. L., Frame, C. L., Simpas, J. B., Harder, H., Martinez, M., DiCarlo, P., Ren, X., and Brune, W. H.: A laser induced fluorescence instrument for detecting tropospheric $\mathrm{OH}$ and $\mathrm{HO}_{2}$ : Characteristics and calibration, J. Atmos. Chem., 47, 139-167, 2004.

Ganzeveld, L., Eerdekens, G., Feig, G., Fischer, H., Harder, H., Königstedt, R., Kubistin, D., Martinez, M., Meixner, F. X., Scheeren, H. A., Sinha, V., Taraborrelli, D., Williams, J., VilàGuerau de Arellano, J., and Lelieveld, J.: Surface and boundary layer exchanges of volatile organic compounds, nitrogen oxides and ozone during the GABRIEL campaign, Atmos. Chem. Phys., 8, 6223-6243, 2008, http://www.atmos-chem-phys.net/8/6223/2008/.

Guenther, A. B., Monson, R. K., and Fall, R.: Isoprene and monoterpene emission rate variability observations with eucalyptus and emission rate algorithm development, J. Geophys. Res., 96, 10799-10808, 1991.

Guenther, A., Nicolas Hewitt, C., Erickson, D., Fall, R., Geron, C., Graedel, T., Harley, P., Klinger, L., Lerdau, M., McKay, W. A., Pierce, T., Scholes, B., Steinbrecher, R., Tallamraju, R., Taylor, J., and Zimmerman, P.: A global model of natural volatile organic compound emissions, J. Geophys. Res., 100, 8873-8892, 1995.

Gurk, Ch., Fischer, H., Hoor, P., Lawrence, M. G., Lelieveld, J., and Wernli, H.: Airborne in-situ measurements of vertical, seasonal and latitudinal distributions of carbon dioxide over Europe, Atmos. Chem. Phys., 8, 6395-6403, 2008, http://www.atmos-chem-phys.net/8/6395/2008/.

Hard, T. M., O’Brien, R. J., Chan, C. Y., and Mehrabzadeh, A. A.: Tropospheric free radical determination by FAGE, Environ. Sci. Technol., 18, 768-777, 1984.

Heard, D. E. and Pilling, M. J.: Measurement of $\mathrm{OH}$ and $\mathrm{HO}_{2}$ in the troposphere, Chem. Rev., 103, 5163-5198, 2003.

Holland, F., Hofzumahaus, A., Schäfer, J., Kraus, A., and Pätz, H. W.: Measurements of $\mathrm{OH}$ and $\mathrm{HO}_{2}$ radical concentrations and 
photolysis frequencies during BERLIOZ, J. Geophys. Res., 108, 8246, doi:10.1029/2001JD001393, 2003.

Jöckel, P., Tost, H., Pozzer, A., Brühl, C., Buchholz, J., Ganzeveld, L., Hoor, P., Kerkweg, A., Lawrence, M. G., Sander, R., Steil, B., Stiller, G., Tanarhte, M., Taraborrelli, D., van Aardenne, J., and Lelieveld, J.: The atmospheric chemistry general circulation model ECHAM5/MESSy1: consistent simulation of ozone from the surface to the mesosphere, Atmos. Chem. Phys., 6, 50675104, 2006, http://www.atmos-chem-phys.net/6/5067/2006/.

Kubistin, D., Harder, H., Martinez, M., Rudolf, M., Sander, R., Bozem, H., Eerdekens, G., Fischer, H., Gurk, C., Klüpfel, T., Königstedt, R., Parchatka, U., Schiller, C. L., Stickler, A., Taraborrelli, D., Williams, J., and Lelieveld, J.: Hydroxyl radicals in the tropical troposphere over the Suriname rainforest: comparison of measurements with the box model MECCA, Atmos. Chem. Phys. Discuss., 8, 15239-15289, 2008, http://www.atmos-chem-phys-discuss.net/8/15239/2008/.

Kuhn, U., Andreae, M. O., Ammann, C., Araújo, A. C., Brancaleoni, E., Ciccioli, P., Dindorf, T., Frattoni, M., Gatti, L. V., Ganzeveld, L., Kruijt, B., Lelieveld, J., Lloyd, J., Meixner, F. X., Nobre, A. D., Pöschl, U., Spirig, C., Stefani, P., Thielmann, A., Valentini, R., and Kesselmeier, J.: Isoprene and monoterpene fluxes from Central Amazonian rainforest inferred from towerbased and airborne measurements, and implications on the atmospheric chemistry and the local carbon budget, Atmos. Chem. Phys., 7, 2855-2879, 2007,

http://www.atmos-chem-phys.net/7/2855/2007/.

Lawrence, M. G., Rasch, P. J., von Kuhlmann, R., Williams, J., Fischer, H., de Reus, M., Lelieveld, J., Crutzen, P. J., Schultz, M., Stier, P., Huntrieser, H., Heland, J., Stohl, A., Forster, C., Elbern, H., Jakobs, H., and Dickerson, R. R.: Global chemical weather forecasts for field campaign planning: predictions and observations of large-scale features during MINOS, CONTRACE, and INDOEX, Atmos. Chem. Phys., 3, 267-289, 2003, http://www.atmos-chem-phys.net/3/267/2003/.

Lelieveld, J., Butler, T. M., Crowley, J. N., Dillon, T. J., Fischer, H., Ganzeveld, L., Harder, H., Lawrence, M. G., Martinez, M., Taraborrelli, D., and Williams, J.: Atmospheric oxidation capacity sustained by a tropical forest, Nature, 452, 737-740, 2008.

Levy II, H.: Normal atmosphere: Large radical and formaldehyde concentrations predicted, Science, 173, 141-143, 1971.

Madronich, S. and Flocke, S.: The role of solar radiation in atmospheric chemistry, in: Handbook of Environmental Chemistry, edited by: Boule, P., Springer, New York, 1-26, 1998.

Martinez, M., Harder, H., Kovacs, T. A., Simpas, J. B., Bassis, J., Lesher, R., Brune, W. H., Frost, G. J., Williams, E. J., Stroud, C. A., Jobson, B. T., Roberts, J. M., Hall, S. R., Shetter, R. E., Wert, B., Fried, A., Alicke, B., Stutz, J., Young, V. L., White, A. B., and Zamora, R. J.: $\mathrm{OH}$ and $\mathrm{HO}_{2}$ concentrations, production and loss rates during the Southern Oxidant Study in Nashville, TN, summer 1999, J. Geophys. Res., 108(D19), 4617, doi:10.1029/2003JD003551, 2003.

Paulson, S. E. and Orlando, J.: The reactions of ozone with alkenes: An important source of $\mathrm{HO}_{\mathrm{x}}$ in the boundary layer, Geophys. Res. Lett., 23, 3727-3730, 1996.

Paulson, S. E., Chung, M. Y., and Hasson, A. S.: OH radical formation from the gas-phase reaction of ozone with terminal alkenes and the relationship between structure and mechanism, J. Phys. Chem. A, 103(41), 8125-8138, 1999.
Penkett, S. A., Monks, P. S., Carpenter, L. J., Clemitshaw, K. C., Ayers, G. P., Gillett, R. W., Galbally, I. E., and Meyer, C. P.: Relationships between ozone photolysis rates and peroxy radical concentrations in clean marine air over the Southern Ocean, J. Geophys. Res., 102, 12805-12817, 1997.

Poisson, N., Kanakidou, M., and Crutzen, P. J.: Impact of nonmethane hydrocarbons on tropospheric chemistry and the oxidizing power of the global troposphere: 3-dimensional modelling results, J. Atmos. Chem., 36, 157-230, 2000.

Preston, K. F. and Cvetanovic, R. J.: Collisional deactivation of excited oxygen atoms in the photolysis of $\mathrm{NO}_{2}$ at $2288 \AA$, J. Chem. Phys., 45, 2888-2893, 1966.

Ren, X., Harder, H., Martinez, M., Faloona, I., Tan, D., Lesher, R. L., DiCarlo, P., Simpas, J. B., and Brune, W. H.: Interference testing for atmospheric $\mathrm{HO}_{\mathrm{x}}$ measurements by laser-induced fluorescence, J. Atmos. Chem., 47, 169-190, 2004.

Ren, X., Olson, J. R., Crawford, J. H., Brune, W. H., Mao, J., Long, R. B., Chen, Z., Chen, G., Avery, M. A., Sachse, G. W., Barrick, J. D., Diskin, G. S., Huey, L. G., Fried, A., Cohen, R. C., Heikes, B., Wennberg, P. O., Singh, H. B., Blake, D. R., and Shetter, R. E.: $\mathrm{HO}_{\mathrm{x}}$ chemistry during INTEX-A 2004: Observation, model calculation, and comparison with previous studies, J. Geophys. Res., 113, D05310, doi:10.1029/2007JD009166, 2008.

Sander, S. P., Friedl, R. R., Golden, D. M. Kurylo, M. J., Moortgat, G. K., Wine, P. H., Ravishankara, A. R., Kolb, C. E., Molina, M. J., Finlayson-Pitts, B. J., Huie, R. E., and Orkin, V. L.: Chemical kinetics and photochemical data for use in atmospheric studies, Evaluation Number 15, JPL Publication 06-2, NASA/Jet Propulsion Laboratory, Pasadena, California, 2006.

Sinha, V., Williams, J., Crowley, J. N., and Lelieveld, J.: The Comparative Reactivity Method - a new tool to measure total $\mathrm{OH}$ Reactivity in ambient air, Atmos. Chem. Phys., 8, 2213-2227, 2008, http://www.atmos-chem-phys.net/8/2213/2008/.

Stickler, A., Fischer, H., Bozem, H., Gurk, C., Schiller, C., Martinez-Harder, M., Kubistin, D., Harder, H., Williams, J., Eerdekens, G., Yassaa, N., Ganzeveld, L., Sander, R., and Lelieveld, J.: Chemistry, transport and dry deposition of trace gases in the boundary layer over the tropical Atlantic Ocean and the Guyanas during the GABRIEL field campaign, Atmos. Chem. Phys., 7, 3933-3956, 2007, http://www.atmos-chem-phys.net/7/3933/2007/.

Thornton, J. A., Woolridge, P. J., Cohen, R. C., Martinez, M., Harder, H., Brune, W. H., Williams, E. J., Roberts, J. M., Fehsenfeld, F. C., Hall, S. R., Shetter, R. E., Wert, B. P., and Fried, A.: Ozone production rates as a function of $\mathrm{NO}_{\mathrm{x}}$ abundances and $\mathrm{HO}_{\mathrm{x}}$ production rates in the Nashville urban plume, J. Geophys. Res., 107, 4146, doi:10.1029/2001JD000932, 2002.

von Kuhlmann, R., Lawrence, M. G., Pöschl, U., and Crutzen, P. J.: Sensitivities in global scale modeling of isoprene, Atmos. Chem. Phys., 4, 1-17, 2004, http://www.atmos-chem-phys.net/4/1/2004/.

Vranckx, S., Peeters, J., and Carl, S. A.: Absolute rate constant and $\mathrm{O}\left({ }^{3} \mathrm{P}\right)$ yield for the $\mathrm{O}\left({ }^{1} \mathrm{D}\right)+\mathrm{N}_{2} \mathrm{O}$ reaction in the temperature range $227 \mathrm{~K}$ to $719 \mathrm{~K}$, Atmos. Chem. Phys., 8, 6261-6272, 2008, http://www.atmos-chem-phys.net/8/6261/2008/.

Williams, J., Yassaa, N., Bartenbach, S., and Lelieveld, J.: Mirror image hydrocarbons from Tropical and Boreal forests, Atmos. Chem. Phys., 7, 973-980, 2007,

http://www.atmos-chem-phys.net/7/973/2007/. 